\title{
Historein
}

Vol 3 (2001)

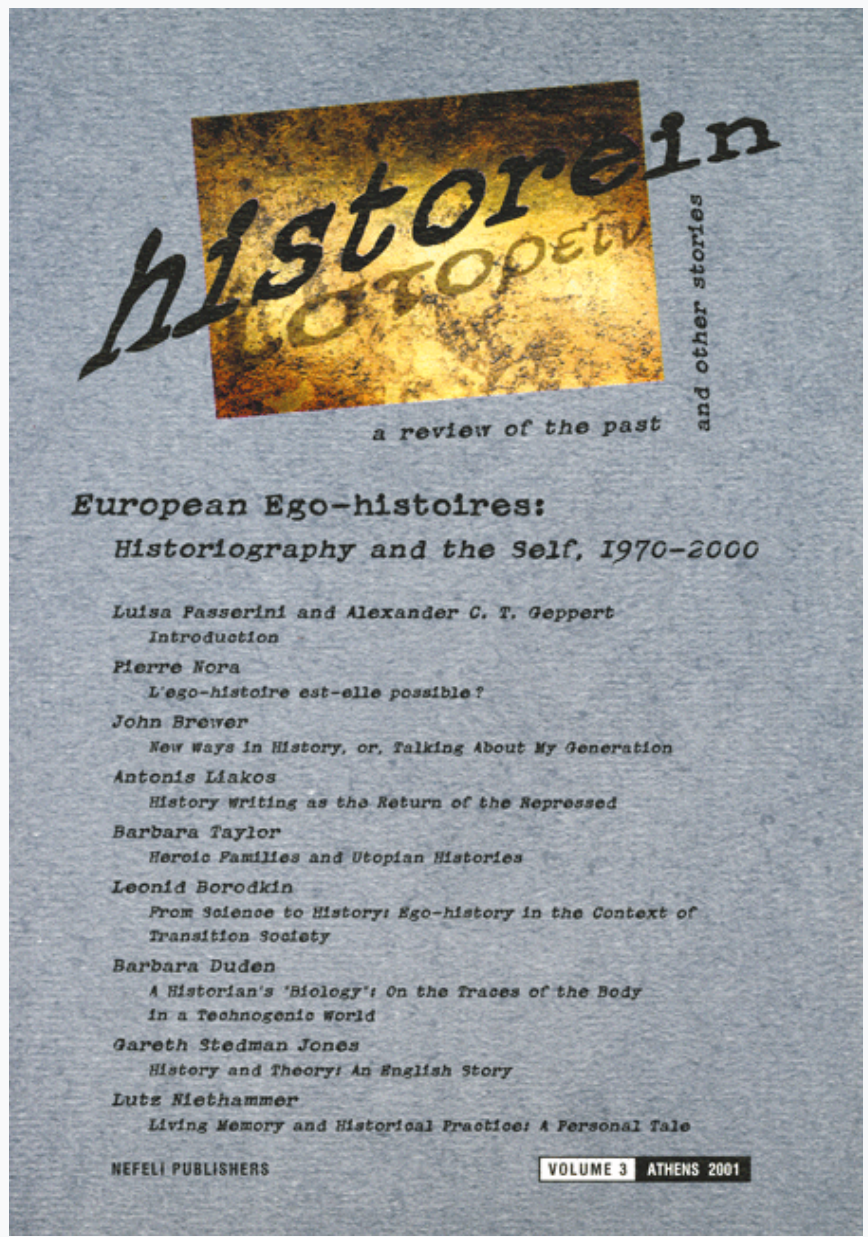

\section{Living Memory and Historical Practice: A Personal Tale}

Lutz Niethammer

doi: $\underline{10.12681 / \text { historein.104 }}$

\section{Copyright (c 2012, Lutz Niethammer}

\section{(2) 1090}

This work is licensed under a Creative Commons Attribution-NonCommercialShareAlike 4.0.

\section{To cite this article:}

Niethammer, L. (2002). Living Memory and Historical Practice: A Personal Tale. Historein, 3, 125-172. https://doi.org/10.12681/historein.104 


\section{Living}

\section{Memory and}

\section{Historical}

\section{Practice:}

\section{A Personal}

\section{Tale}

\section{Lutz Niethammer}

\section{Mastered History? Irritations} About the Suggested Format and Authorship of Ego-histoire

To be invited to reflect publicly on the interrelationships of one's life and work is to be seduced and frustrated at the same time. Seduced because it is flattering that there should be such an interest in my historical practice and person by colleagues from all over Europe, gathered at its most prominent graduate school in Florence. Frustrating because an exposé in ego-histoire in the format of a paper or article seems to me to be an impossible task.

Obviously, the challenge is not to produce an autobiography; that genre of narrative can hardly be put on one's agenda from the outside. If its results are to be any good, it needs a special motive and time in an author's life to be triggered and set off, and then most probably it would run into complexities that would require far more space. Basically this still holds true when, in my own case, the task is to cut down to a working account more than thirty years as an academic historian. The right time in life for autobiographical labours usually is a crisis, when things can no longer be taken as selfunderstood and one is forced to come to grips with his or her own tale, authoring it anew. Less generally, but still as a standard rule, the best type of crisis for an autobiography is a liberating one, when the restraints of institutions, ambition and discretion tend to fade away, measured against the need to compose or correct one's own image or to tell some of the important stories that were silenced before. Significantly, most male autobiographers set to work after losing their institutional power. 
Living Memory and Historical Practice: A Personal Tale

What, then, is an ego-histoire? When I look into some of the French models of that type of narrative, collected in 1987 by Pierre Nora, I find constructions of the specificities of various historians' approaches to their work, more or less replaced in the contexts of their times and professional surroundings, with rare glimpses of their private, even intimate, lives. This is so even with historians who say they were influenced by psychoanalysis, by anthropology, gender, cultural and micro-studies, and it reflects periods and contexts of formation when and where the personal was regarded as the political. I am astonished, but of course I appreciate their discretion.

But it raises questions about the construction of the "egos" at work. The influences of Allied reeducation on my youth were strong enough that, from my student days, I construed my intellectual practice to be at least as much in the tracks of the Enlightenment as it was then schooled by the romantic assumptions of German historicism, then already in decline. But for one thing: the enlightened construct of a gigantic ego, later to be ruined by Freud, and then in a diminished way resurrected for the encouragement of the masses in contemporary middle-class societies by Erikson and other Ego-psychologists, who drew on Jung's theories about individuation and were fascinated by his cult of the genius. Is the ego the sole source of creativity, in reading and writing, in the impulse to select a problem and to get started in what direction, in deciding where to go for what sort of information and where and how to present results or reflections? And in the exchanges when you advise students or younger colleagues or seek advice with others yourself? Or are there other relationships at work, short-cuts between deeper layers of the self and challenges, models, powers, complex attractions and frustrations from the outside world, which to some extent or another, ego may or may not be able to perceive, but which it surely does not control? Of course I know there are colleagues producing many and sometimes very useful texts; they are sitting down at their desks at eight o'clock in the morning and advancing professional knowledge step by step.

But my own experience is different. Take for instance writing: for almost half a century, time and again I have tried, for many good reasons, to tear my writing and interpretative work into daylight, but always in vain. Either it just didn't happen or the results were dull and uninspiring - piecing together available information with professional frameworks in bureaucratic or fashionable languages. Hopefully more often than not, ego then (again) censored what it had produced. Writing with me only happens at night, and I mean it in every sense of the word (with lots of pipes and hopefully less wine). Next morning, the ego then mediates, edits, or cuts out the results of my intellectual nightlife. And during the rest of the day (or month or year), it takes a lot of reading or whatever intake of information has to be done, to allow for further intuitions and to make composition possible again the next time. With me, the ego is construed as a mediating and controlling institute, dominated by rationality, but if there were nothing else responsible for generating, there would be hardly anything worthwhile for the ego to edit. Or take the advising of research students (or similar visitors in search of advice), for me the central job of a professor and, being 
a poor teacher in collective situations, the only one that I think I can be really good at, at least now and then, when "it" happens. In such situations I carve out all other considerations and try to be completely at the attention of my visitor. The exchange then is always very friendly, but it can reach the extremes of professional critique and the depth of our motives as well. We may sit for the rest of the day, or take a long walk, getting very personal indeed and very much to the point of the subject matter under review, hopefully generating strategies of inquiry that are apt to both the author and the problem. On such an occasion it is not only egos that relate somehow and stimulate one another, but all sorts of textures between our selves, including the presence of dimensions of the outside world, some of them under rational control, others well beyond its reach.

Another astonishment was even more bewildering to me: most of these ego-histoires, relating the development of the author's approach and œuvre, seemed to be able to make sense of this development, apparently the precondition of the short version of ego-histoire. In most cases there seemed to be a continuity in view of their development as well as a sort of subjective and meaningful programmatic that they had meanwhile acquired, which sounded to me as if they were the masters of their histories. Were they? Did they think they were? Or was it the format and context of their narratives that had suggested a continuous flow and a happy ending? Maybe my impression was wrong, but my irritation was there and it had - beyond my inability to cut long stories short - at least two causes. The first had to do with my own feelings about my life and work, suggesting that my feelings were far more fragmented and open-ended than I had supposed and that I certainly was not the master of my histories, let alone of my life. But if an elderly historian was asked to tell his ego-histoire, was he or she not regarded as able to tell a story with a meaningful ending that could tell others about a field mastered, that is, about how "to do it"? My problem was neither one of overdone modesty nor the frustration of someone who in old age, looked back on his life and work and felt that he had achieved nothing. The question was more one of authorship, and about how to reduce a useful message.

The second reason for my irritation was rooted in my experience as an oral historian of life-cycle interviews and, more generally, of two decades of coming and returning again to the problem of memory, individual and collective (and gratefully I want to acknowledge here that I was long ago introduced to these problems by Luisa Passerini). Taking the "communicative memory" of those still around, I knew that most people by now in Central Europe could present a version of their curriculum vitae, grouped around basic data of their descent, formation, career, and family, and that most of them also presented a hidden or outspoken pattern of how to explain the generality and specificity of their lives in socially acceptable terms, sometimes even a statement about the meaning of their life and accomplishment. In Germany many elderly interviewees usually had narrated their personal experience within, or against the backdrop of, the discontinuities of twentieth century German history and its major events, discontinuities that had structured for many their experience of time, that had changed their lives in unforeseeable and dramatic ways, that had put 
in question their personal identities, even their survival. Against this backdrop, the sense of longrun success in life among many resembled a sort of individual luck and muddling through ("Durchkommen") rather than accomplishment, pride or the advance of a tradition. As the interviews went on, however, these sorts of life stories for social uses, with well established references and acceptable patterns of meaning, unfolded into something much more complex and fragmented, full of relationships and little scenes from memories that sometimes fit into overall pattern and sometimes did not. Those that did not usually proved to be keys for interpretation, because they were uncensored from later explanations and social acceptability. The overall patterns thus got a history of their own, when perceived from the unintegrated slips of reminiscences which the interaction with an unknown interviewer, a screen for all sorts of transferences, had liberated in memory. The more we got away from a mastered history, the more we touched real ground - if only in fragments, to be puzzled together anew - and the more we learned about the making of hegemonic sense and the limits of its powers of integration.

In short, I feel the format and the construction of authorship of ego-histoire not to be feasible for me. So what can I do between temptation and frustration? I can only offer a much more questionable and fragmented substitute. First, I try to reflect on my practice as a specialist in contemporary history, or what Germans call "Zeitgeschichte" (history within living memory), looking at it from an unachieved end. Second, I shall sketch very briefly some ideas on the relationship of memory and history. Finally, I will offer a small extract from my own recollections were I asked to present them in a semi-public context for historical purposes. And in the end I will leave it to you to let history and memory comment on one another.

\section{About the Involuntary in My Historical Practice: Personal Reflections}

Since most historians think of writing as the centre of their practice, I will start by looking back on my publications, especially what they look like as a whole, in terms of methodological and thematic coherence. Then, I will point to other fields of practice of an academic historian and the social contexts that co-authored my work. And, third, I will suggest a sort of hidden agenda behind the inconsistencies of the present author.

\section{1 Diversity and Eclecticism}

The first problem I find with my published work is that it lacks thematic and methodological coherence, an evident evolution and a sense of time and planning. Since time is the basic dimension of history, I find my lack of ability to handle it in my own work rhythm quite troubling. A dear friend and respected historian, who has published readable books of some two- or threehundred pages in a continuous flow of perceptible stages, once told me how he is planning his œuvre, putting one step before the other. Nothing could be less characteristic of my own publications. 


\section{Publications}

Let me first look at my publications. For convenience I try to characterise their topics and times, at least those books which are listed here in English (along with their year of publication). In an appendix I list the German bibliography in chronological order and add some of the articles and the one book that have been translated into English. Some of these publications, including various papers and articles that have been put together and reissued under the title Germany Thereafter [1999] by my friends and former assistants on the occasion of my sixtieth birthday, answered public challenges. As did two books (on post- and neo-fascism [1969] and on Communist capos in the concentration camp of Buchenwald and after [1994]) that were produced within months for timely intervention in public debates, ruining all other plans. On the other hand, it took me seven years to write my dissertation on American de-Nazification in Bavaria [1972], which then sold in one of Germany's most prestigious publishing houses a devastating 390 copies, but which was more successful ten years later when reissued under a more sexy title (The Production of Followers).

I had not even finished my dissertation, when I began to edit the private papers of Walter Dorn, General Clay's advisor on de-Nazification [1973], an American specialist of early Modern European history and in some ways a kindred soul. My planned Habilitation on the European discourse of working-class housing and spatial social control was never written, because in 1973 I got a chair when I was in the middle of research for the project in England. In 1978, after two years of being dean of my department, I sought and received time off to complete this research in France, but I never settled down to write the book, becoming vice-president of my university instead and scattering some of the results in articles and in advising others. These substitutes became a comparative article on spatial social control in England, France and Germany up to the First World War, largely a blueprint, shelved in an American reader on urban history [1981] and never published in German. Two articles (together with Franz-Josef Brüggemeier) on workingclass housing in Germany and its meaning in the Ruhr. A collection of essays (all about German housing, including one of my o'wn) entitled Dwelling in Change, edited by me [1979]. And my own favourite little booklet on a Communalbaumeister, who had gone crazy in his ambition to urbanise an industrial village in Wilhelmine Germany. Its title was (to quote just the first of some of my awkward titles on the history of the Ruhr-district, Europe's most extended industrial agglomeration, housing in the end some five million people) "Circumstantial explanation of the psychic troubles of a local planning officer in Prussia's biggest industrial village or The inability of urban development" [1979]. In fact it consisted of a programmatic article on the urban- and "Alltags"-historical approach to industrial agglomerations, disguised in a biographical sketch of some thirty pages, considerably enlarged by archival documents and nineteenth century maps and photographs, some of which an artist and colleague, my friend Hermann Sturm, had collaged and deciphered with ingenious drawings. But in my own work, that programmatic essay was almost the last piece of urban history, but for a few scattered articles and the fact that I was included on the editorial boards of two outstanding journals of urban history in France and 
England. Two of my more recent studies (on Posthistoire [1989] and on collective identity [2000]) were planned as critical commentaries on fashionable "theories" of the ' 80 s and ' 90 s. Each was to be written in a summer as a short and readable pocket book, but they drew me into major excursions into intellectual history and years went by till they were finally published, the latter having accumulated some 670 pages of small print and thereby completely lost its purpose as a public intervention. Various publications were the result of team-work, such as on anti-fascist liberation committees in Germany 1945 [1976], the impact of the Marshall Plan on the European Left [1986], oral histories of the experience of working class people West and East 1930-1960 [4 vols. 1983, 1985, 1991], an invitation to people's history in what was then my region of Northrhine-Westfalia [1985], a textbook on civil society in Germany since around 1800 [1990], that was completely lost on the public; turning then to communism and national identity, including the documentation Between Liberation and Occupation from the archives of the American secret service [1977, reissued 1995], an edition of Russian documents on Soviet camps in Germany 1945-1950 [2 vols., 1998] and the Capo book, mentioned earlier on. Most of this team-work has been quite close - and the bigger the team was, the more it proved to be time-consuming - with me often being the team leader but much of the best insight for the overall projects and some of its most rewarding texts coming from fellow authors.

\section{Themes}

When I try to group my own writing and the animation of more or less collective projects by themes and subject matters, some centres of gravity emerge. One, the impact of the Allies and the Cold War on the perception of post-fascist problems (including the transformation of the extreme Right) and anti-fascist (and more generally leftist and trade union) perspectives in Germany and Europe. Two, spatial aspects of social control, popular experience and cultural symbols in industrial regions and more particularly the Ruhr district. Three, the perceptive structures of popular experiences as mediators of continuity through the discontinuities of German history in the mid-twentieth century, including rising individualisation and fading infrastructures of collectivism among the working classes in different varieties in West and East. Four, the roots of widespread concepts of the later twentieth century in the intellectual history of the aftermath of World War I and of totalitarian ideology. Five, the history and heritages of camps (and of forced labour) as the most infamous sites of the breakdown of German and other European civilisations. Such a list is intriguing enough, but in my view it would have to be topped with the themes of projects abandoned (the spatial discourse of social control in nineteenth century Europe, a history of the future in the twentieth century) or still not achieved, like the pieces of puzzle of a political, social and cultural history of Germany, including its international ramifications and the workings of public and private memories in both West and East since 1945 and beyond 1990, which is still at the top of my agenda. But this agenda also includes the animation of two additional collective projects, on the cultural history of infrastructures and the impact and challenge of intergenerational transfers of experiences from the GDR into the now evolving youth cultures in East Germany. 
For me such themes and subject matters are not really unconnected, but I am stuck when I have to explain the diversity to others. Could I only explain it in autobiographical or generational terms? Who co-authored the variety of these interests? Am I an opportunist in opposition? One thing seems to me to be quite evident from such a survey: in contrast to many a painstakingly specialised scholar, who keeps to a chosen line and problematic and hopefully will, on top of the piles of his or her specialised knowledge, end up with a big breakthrough, I was much more tied to questions of my time and surroundings, taking them up in order to give them a different turn. I worked on the assumption that after a couple of years, one should change field of specialisation as well as methodological approach. Looking back I am still not sure whether this was prompted by changing outward influences and challenges, by curiosity, or by a conviction that if one spent five or ten years on a problem and did not come up with results, or at least a debatable intervention into the set of questions, one's own contribution probably was not really worthwhile. Or by whatever mix of the three. I do not want to overdo this point, since my work was restricted to a relatively limited field in the time span of European history and within this already limited field, it was nationally biased and sometimes quite parochial. Still, there remains an insecurity about the sources of authorship of one's own writings.

\section{Methods and Sources}

Even though a decade ago I was regarded among German colleagues as "Mr Oral History," after having edited and contributed to five or six volumes in order to probe and prove the usefulness and academic acceptability of this method in German history, I myself, again, do not see a dominating methodological approach in my work. My lectures at university largely have dealt with a somewhat socially and culturally extended political history, as did my dissertation. Quantitative and comparative operations have always been central in my way of forging linkages between social and political aspects of history. And in my studies about concentration, labour and similar camps - provoked during the last decade by advisory jobs on the remodelling of the commemorative site of Buchenwald and the very late compensation of Nazi forced labour by German industry and government - I could not only invest a certain amount of expertise with life histories and the experience of victims, but I had also to learn unwillingly the horrible lesson that in any comparison and history of such camps, the death toll is an indispensable indicator and instrument of research.

The same picture of an eclectic (and in some fields amateurish) methodological experimentation holds true when I look at the sources I used. Certainly, I can recognise periods in which I concentrated largely on one type of evidence: the texture of American and Bavarian archives early on. In a middle phase the co-production and interpretation of oral recollections. And in a later period, published material on and of intellectuals, be it to uncover the origins and interplay of their ideas, or to synthesise research done by others. But in the first phase of archival pleasures I also evaluated parliamentary debates. I tried to make sense of public opinion polls. And I compared the images and maps of cities, industrial agglomerations and varieties of housing, 
even including the collection, interpretation and investigation of documentary photography of the Ruhr region - well into the second phase of my oral history adventures. These were, on the flip side, combined with the interpretation of Nazi films and of archival "ego documents," types of sources I taught about considerably and wrote about little, or more recently of the oppositional leaflets during the fall of the GDR. This did not preclude continuing earlier comparative work, based on the research of others, on fascist movements, the post-war European labour movement, or later on camps (or, as in my current teaching, the process of European integration); nor did it preclude falling in love with intellectual history, as I did.

\section{Schools}

Again, when I turn to the theoretical references of my work, I find the same eclecticism. Even though I gratefully enjoyed the company and inspiration (and sometimes even a sort of conspiratorial fighting spirit) of various teams and networks, I never had the feeling that I belonged to a school. And the courageous individualistic resistance of my assistants and research students wiped out all of my own temporary temptations to do more than advise them and direct them instead to my favourite interests, which, happily, was almost always an utter failure. To be sure, I am proud that all assistants to my chairs at Essen and Hagen later became professors themselves, and that we stayed friends. But most of them worked in or developed different fields, finding approaches of their own: Ulrich Borsdorf in museology, Othmar Haberl in East European studies, Alexander Schölch in Middle Eastern studies, Detlef Peukert in the interwar period, Franz Brüggemeier in environmental history, Ulrich Herbert in Nazi history, and Dorothee Wierling in the fields of gender and education. With almost every one of them I did very close teamwork at times, and advising these brilliant people meant learning and pleasure for me. But certainly we do not constitute a school of thought. If there is anything that characterises us as a group, I would describe it rather as a sense and joy of the sociability of knowledge, as a directing of historical studies towards interventions into public memory.

On the other hand, this should not sound as if I were not grateful for the chances and stimulation that I got when I myself was near more school-building masters like my "Doktorvater" Werner Conze. Conze was a conservative innovator in grounding political in social history and a man of great standing. He also, as we later learned, had been in his youth a member of the intellectual teams that paved the way for the ethnic cleansing of Eastern Europe by the Nazis. (He was very tolerant with my selection of a sensitive subject as well as of the rather long span of time I worked on it, but in the end didn't particularly like the result.) Or Hans Mommsen (who picked me as his first assistant even before I had a doctorate or, for that matter, any exam at all), a social-democratic fighter against nationalism and conservatism. Together with Martin Broszat (who advised my first editorial work on Dorn), he was the protagonist of the structuralist approach to Nazi history. Later, from 1972 onwards, I profited in England from my contacts with an innovator of urban history, Jim Dyos, and from friendships with the editors of Social History, especially Keith Nield; as well as within the History Workshop movement, among whom I should at least mention 
Anna Davin and the late Tim Mason and Raphael Samuel, who introduced me to the radiation of E. P. Thompson and the romanticism and empiricism of British Marxists. In France in 1978, I had a chance to participate in one of the last series of seminars by Fernand Braudel and to get some insight into the transformation of the Ecole des Annales. But I was even more fascinated by occasional meetings with Pierre Bourdieu and got into a working relationship with younger Foucauldians such as Lion Murard and Patrick Zylberman. To such impressive influences, of course, I should add masters long deceased, whose writings had, at different times, a strong impact on my views such as Droysen's Historik, various sociological works by Maurice Halbwachs and Henri Lefèbvre, or later Benjamin's "On the concept of history." Even though I could go on and on, I stop this name-dropping here, because I only wanted to illustrate three things at a time. During my professional formation, (1) I had chances to see some of the most: productive schools of historical research and practice from the inside and I profited greatly thereby. But (2) I did not stay in one school, was impressed with rather conflicting influences, and took my experience with these schools more as intellectual journeys. And (3) these influences quickly transformed in the ' 70 s from schools into a variety of loose, cooperative networks that were tied together by common interests rather than the same point of departure, by joining different references and styles and by friendly curiosity - which in some cases left long-lasting friendships. I will come back to the impact of institutions and networks on my work.

\section{Theory}

Let me here just add that theory - and this seems to me to be a strong indication of belatedness against my age cohort in Germany - came only late into my formation and I had to learn still a lot, when I was already long into academic teaching. But increasingly I liked to learn about theories, up to the present day. Many of my cohort among German academics were strongly and abruptly influenced, if not converted, from the mid-sixties onwards, by the Frankfurt School, by some variety of Marxism or by psychoanalysis. In my case, this was different. Although I then read a lot of theories of fascism, it was more a topic of my research on de-Nazification and neoNazism and only a few writers (like Bloch, Thalheimer, and Franz Neumann) left long-lasting suggestions. About Marx I did not know much more than standard school stuff. It was only in 1972, and in Oxford of all places, that I felt that this was a grave deficiency and joined a couple from Brazil, a Japanese, and some others from the international student community there for an in-depth and critical reading of Das Kapital - in English. I had distaste for people whose only practice was theory, and even more the then fashionable gesture of theoretical deductions among newly converted Marxists. I may have started late and certainly never became a Marxist, but even nowadays when Marxism is so out of fashion, I cherish some of his writings like the 18th Brumaire or on the Paris Commune.

The reason behind my circumvention of philosophical studies as a student, which put long reading lists on my agenda in middle age, probably was that I had started out as a theologian, getting my basic instruction in historical criticism in the reading of holy texts (mainly from the Hebrew 
Bible). I am grateful to the present day for this careful and serene schooling. Nobody is more knowledgeable about their few sources and less dogmatic than Protestant scholars of the Old Testament, or at least those who instructed us in the early '60s at Heidelberg and Bonn, such as the superb Gerhard vom Rath or Martin Noth (as well as the dear old Rabbi Sprecher from Poland, who introduced me to the thinking of Talmud and Mischna and even into some basics of Yiddish). But when we arrived, after four years of language training, exegetics and historical studies of religious institutions and thought, at dogmatics (theological philosophy), I broke off altogether because I discovered that my agnosticism was insurmountable. I just could no longer follow these dons and, looking back, I am not so sure whether it was their message or rather their style of authoritative deductive thinking that finally led me to drop out and concentrate on history and social sciences. I stayed grateful for my basic education in reading and historical research with the theologians, and I kept my respect for people who believed and acted as Christians; but for my part I became immune to dogmatism in whatever covering.

This background of my eclecticism restricted my theoretical interest for a long time to the critique of ideologies and to the use of middle range theories as debatable instruments to gain and organise knowledge. My economical defence was "I think, when I have to," i.e. when I am stuck with a problem and when, what is more (and only then begins scientific research), I have been able to transform it into a set of questions; then I turn for advice to theoretical literature. It took almost two decades till my interests in Alltagsgeschichte (everyday- or more precisely socio-cultural history), oral history and discourses around memory had manoeuvred me enough outside established historical assumptions that I realised that instrumental eclecticism was not enough. Even then I did not select some giant, climb on his shoulders and translate his wisdom into today's problems. But I did become more and more interested in what ways and for what reasons these giants had mapped the ground, and why ordinary people like us should still uphold such superhuman perspectives. Even though I hate the fashionable rhetoric of deconstruction and would be more attracted by Benjamin's term of "rettende Kritik" (rescuing or redeeming critique), much of my latter historical practice seems to work in this direction.

\section{2 Beyond Oeuvre}

German professors are state officials expected to divide their time into three equal parts: teaching, research, and administration. By international comparison, the first point varies and may be somewhere in a middle field, the second is uncontrollable in the arts, at least in terms of quality, and the third is rather peculiar, since some university systems abroad are not self-governed, others are (but in a more efficient way). The peculiarity of the German system is a threefold administration: 1) collegial and co-determined self-government by all sorts of more or less influential boards and committees; 2) under an often exceedingly bureaucratic state control; and 3 ) deriving all extra finances for research students and projects from a very complex system of public, private and semi-public foundations (the latter being by far the largest part) that divide their riches through committees operating on an extremely time-consuming system of 
elaborated and competing evaluations of the again very elaborated projects proposed ("Gutachten," not to be confused with the "letters of recommendation" in the English-speaking world, being in many cases more similar to the elaborate reasoning of judicial judgements). Of course it can be instructive and network-building for the participants, as well as a means of patronage and its checks at the same time, but by the charms of power it eats up more and more of their time, energy and writing. I often thought that the major part of my "œuvre," written at daytime, was silenced in piles of project proposals and confidential Gutachten.

If you are working in a field, like contemporary history, that is oriented towards the public, you have more than average chances of spending additional time and energy on book reviews (this I skipped almost completely), public comment, further education (especially of teachers, which I did a lot) and in all sorts of initiatives and advisory bodies in the realm of public history, museology, preservation of cultural heritage, historical publishing, didactical programs, publications, and competitions and the like. Many German historians devote a large part of their creativity to such extramural public or secret activities, which have grown considerably since the mid-'70s. I must confess that almost from the first months after I had become an assistant in early 1968 at the first newly founded university of the Ruhr district in Bochum, I was quite active in both institutional administration and reform, as well as in networking and professional and public initiatives. And I stayed so during my work in three other newly established academic institutions there (the Comprehensive University or Geamthochschule at Essen since 1973, the German version of the Open University or FernUniversität at Hagen since 1982, the Institute for Advanced Cultural Studies or Kulturwissenschaftliches Institut im Wissenschaftszentrum NordrheinWestfalen again in Essen since 1989). I finally left the Ruhr after twenty-five years to go east into the former territory of the GDR in 1993 and teach at the "new" (actually old) University of Jena, where I tried to restrain such activities, without much success.

I cannot help but tell a bit more about these institutional and public activities because for one thing, they were triggered by the opening up of academic life after 1968. Two, my version was just one among many characteristic of the outgoing spirit of that time, as well as its illusions. And three, these activities were a continuous school of further education for myself and deeply influenced my thinking about history and memory. Before I go further, it may be noteworthy that I never belonged to a political faction as many of the '68ers, nor to a political party, but have in my rather stable leftist liberal flexibility, at certain times and on certain issues, networked with almost all of the established parties, cooperating mainly with social democrats and trade unionists. These I only got to know more intimately during my years in the Ruhr where their political hegemony was grounded in regional socio-cultural roots. Probably I should also add that from early on I became familiar with the public domain and the media, founding and editing with others for some years a printed pupils' journal at my secondary boys' (and the neighbouring girls'!) school at Stuttgart. As a title of the journal I had chosen filia + filius, and if you ever get to the end of this essay, you will find this name to be astonishing enough, not only because I had failed school 
in the previous year because of my bad marks in Latin. Later I chaired the regional federation of the youth-owned press (jugendeigene Presse) and earned much of my living, when I was a student in Heidelberg, by writing longish scripts for educational and cultural programs of various broadcasting stations with a view to becoming a journalist. After I had changed subjects, I won a nice scholarship (Studienstiftung des deutschen Volkes), which took the financial need out of publishing. Finally, I got stuck as a historian by academic opportunity.

\section{Self-Government}

My career as an academic administrator, so to speak, began in spring 1968, a couple of weeks after I got my first job as assistant, at a general meeting of the Bochum history department where the revolting students struggled for institutional reform in a rather wild and dogmatic fashion, which the professors declined. Largely because I could not bare the tensions in this crowded assembly I advanced the core of the students' program for equal representation of professors, assistants and students to be, in consideration of the differentiated needs within the department, a guideline for a more pragmatic procedure. Within an hour, I found myself elected to the chair of a reform body that over some weeks drew up a new statute for the department, with "Drittelparität" and the consent of most professors. It was the second such statute put to work in Germany, the first hot place being among political scientists in West Berlin, and it worked for something like a decade. After this promising start we formed a second reform group to restructure the syllabus. But the participation of students and professors alike faded away and nothing resulted but a long-lasting one-year introductory course, where specialists from ancient to contemporary history coordinated their teaching, most introductory courses being in the hands of us assistants anyhow.

After I had, to my great surprise at the age of thirty-three, become a full professor myself, I served - taken together - for some nine years as chairperson of the historians in different places, and even longer as a member of various central committees and university senates, two years as dean of humanities, two years as vice-president for education and four years as ministerial commissioner to get the already mentioned Institute for Advanced Cultural Studies started. Not to speak of more temporary assignments to advisory boards and project committees of a number of foundations and other institutions, including some fifteen years on an historical advisory board that the president of the German trade unions federation assembled once or twice a year. Obviously I was a man of institutions and one of the typical reformers and builders of academic institutions of the '70s and '80s. I can neither deny that I invested a lot into these activities nor that most of my major reform initiatives failed. For instance, the reform of teachers' education in Essen (which was just through when our state ministry for education had hired the last teacher for some one or two decades) or the opening of the German Open University at Hagen, which in fact is called University for Distance Education or FernUniversität, for a system of further education in the humanities. Changes in atmosphere and approach worked as long as we could practice them within a single institute in the loopholes of the overall machinery. But when it came to 
tackling the structures of the wider machinery and when we had won academic consent to make them more intellectually creative and less self-enclosed, we usually did not get political approval. We met with the lack of time, courage or knowledge among politicians and, more decisively, the power of high-ranking bureaucrats who thought in administrative regimes rather than in terms of culture and education and were all but prepared to loosen their technocratic grip on academia, wasteful and frustrating as it was and is. Sorry to say that this was especially true with my socialdemocratic friends. The basic experience of these engagements for me was to get expertise in analysing institutional problems, in negotiating, integration, counselling, and in losing against political authorities. In other words: to be in and out at the same time, a well-established outsider.

\section{Apprenticeships in Compromise and Dissent}

Under these conditions, to be an academic of institutions, networking among alternative initiatives in academia and in public was not so separate an activity. Let me give a few examples that were important to my formation after 1968 .

Many German '68ers were aroused by what seemed to them a resurgence of fascism everywhere, in America's war in Vietnam, in De Gaulles' "télécratie" in France, in the closure of the political class in the great coalition at Bonn, in authoritarian family structures, or in modern capitalist societies at large, and some of their spokesmen lamented the "helplessness of anti-fascism" that did not address the capitalist foundations of fascism. My focus then was more practical. I had the feeling that we should do something against the resurgence of neo-fascism, which had, by merging declining post-fascist groups in 1965 in the National Democratic Party (NPD), established itself in one state election after another as a political factor, rising from six to more than ten percent of the electorate. In the general election of 1969, it threatened once again to eat up the votes of the small, but decisive Liberal Party in between the conservatives and the Social Democrats, thus either prolonging their cooperation, which was only effective in modernising infrastructure, and delegitimizing or blocking alternative politics, or forcing the conservatives unwillingly back into a brown coalition. In my evaluation it was decisive to rescue the Liberal Party, a strong advocate of small-scale capitalism, from the dangers of vanishing and giving way to neo-fascism.

It was in this setting, that I abandoned my thesis and my academic politics of institutional and curricular reform for almost a year and, together with Hartmut Pietsch, wrote within months, in the otherwise hot winter of 1968/69, a cool book on the reality of the parliamentary politics of the NPD and on the transition from the post-fascism of old Nazis, only too eager to adapt and be accepted, to the neo-fascism of the kids of the Cold War, who were prepared to take up fascist interpretations again and act them out in a much more dynamic way, unleashed by the good conscience of late birth. In this I made two compromises, that were, I guess, unthinkable for most of my (then growing number of) friends within the radicalizing Left. I approached our secret service, which was watching over the activities of extremists Left and Right (Bundesamt für 
Verfassungsschutz), but that was the principal foe of leftist radicals at the time, blocking their careers in the civil service; I found that its department for right-wing extremists had gathered a wealth of evidence on the NPD, but was helpless in evaluating its data. Our deal was that I would help with historical interpretation of these data on politics and personnel, and in exchange I could use this knowledge for our public interventions. This intimate knowledge enabled me to give a much more accurate account of the inner dynamics of the party, which was even acknowledged by the leader of the party, Adolf von Thadden, who wrote me, after his retirement, a surprising letter from his retreat on Mallorca. The second compromise was that I got together with the leadership of the Liberal Party (such as the Friedrich Naumann Stiftung), then afraid of losing their lower-middle-class base to the neo-fascists, and toured the country from coast to mountains to meet their rank and file in the back-rooms of smoky pubs, and tell them how they were going to be let down in their aggrieved attitude by the actual politics of the NPD. I remember that Bernd Weisbrod, one of the most intelligent students of the '68-generation at Heidelberg, then a teaching assistant to Mommsen's chair, and later Professor of Modern History at Göttingen and a close friend, accompanied me on one of these many trips in the spring and summer of 1969 and was as disturbed by the speed of my driving as by the compromising attitude of my politics. Nobody really can evaluate the impact of such a small personal engagement, but I am still proud of it. Our book came too late, almost coinciding with the defeat of the NPD in the general election (by a very small margin indeed). The two decisive factors had been, one, that most of the media had presented the NPD as getting more and more violent - building up a cadre to watch over their embattled demonstrations (Ordnerdienst), which to Germans resembled the storm-troopers of the Nazi Party - and two, that German industry had combined for the first time in an advertising campaign in the summer of 1969 to remind the voters of the export interests of the German economy. And maybe, my tour of the provincial back-chambers of the Liberal Party had also contributed just a little bit, in that it had not only not lost to the NPD, but had become the instrument of changes in power from twenty years of conservative rule as well as an opening up of progressive perspectives within the Brandt government. These tours also had an effect on me personally in so far as they unleashed my tongue from the shyness of youth and introduced me to the complexities of ordinary Germans.

I can't really remember how I got involved, but I guess it was due to the overburdening of Hans Mommsen with public engagements and his passing on this challenging invitation to me, that, just after the completion of my dissertation in 1971, I became a member of a major study group of the Deutsche Gesellschaft für Auswärtige Politik, an equivalent of Foreign Affairs in America and a highly influential semi-public body. This research group, on perspectives of the West German state, consisted of some thirty scholars from all fields of the social sciences. It was initially provoked by the Neue Ostpolitik of the Brandt government and was headed, on one side, by Karl Carstens, then directing the society's research institute, a senior official of many bipartisan moves in German post-war politics (later, suddenly to become the leader of the ChristianDemocratic Party and even later a rather conservative federal president), and on the other, by 
Richard Löwenthal, the theoretical head of an anti-fascist group, Neu Beginnen, that had manoeuvred between the big tankers of the Left in resistance and emigration politics, a professor of international politics in West Berlin, and one of the closest advisors of Willy Brandt. Behind the scenes, the strings of the project were pulled by Eberhard Schultz, a Iong-time SocialDemocratic deputy of the institution, a pioneer in preparing the Neue Ostpolitik for a decade, and one of those influential Germans in the background, whose rationality and Protestantism included a high amount of ascetic pre-disposition to suffering ("drilling thick boards of wood," as Max Weber once defined politics). I was entrusted with a basic paper on the traditions and perspectives of the nation state in the German setting and wrote some hundred pages (including the evaluation of a public opinion poll, that I had conducted together with Ulrich Borsdorf, on notions of nationality in West Germany). There were two basic points. For one, national perspectives had rested with the Left after fascism, because the usually more nationalist groups of the Centre and Right had fled to all sorts of supra- and sub-national perspectives. Two, we advanced, on the tracks of Karl W. Deutsch's theory of nationalism, the idea that a process of bi-nationalisation within Germany as a whole was under way, and that this was much more effective in the West than in the East. This paper (reissued in Deutschland danach [1999]) has in retrospect provoked some denunciation - of undermining faith in the German cause at a time in 1990 when declining West German nationalism was being re-kindled by reunification -, but the alarm against the traitor faded when he went East, and when it turned out in the ' 90 s that eastern self-consciousness was not so easily subsumed into what West Germans regarded as normalcy.

Within the project on perspectives of West German foreign policy, in 1971, another problem was far more explosive. It was an empirical, and rather Marxist, reading of the powers of capitalist progressivism within European integration, and its challenge to democracy and the nation state. It was advanced by, on the one hand, Heinz Kuby, a very impressive mix of Frankfurt leftist with the living tradition of Stefan George, and who was then a radiant director of information within the European institutions at Luxembourg. He died unfortunately young. And, on the other hand, there was his Austrian friend Erich Kitzmüller, the most practical and friendly theoretician I ever met. This Socratic seducer, and his sister Rosie, a big, Styrian witch of great warmth and intelligence, and a most delicious cook of strictly regional dishes, were to become a singular experience for me, and with them I later spent, between my two marriages, that is for almost two decades, every Christmas and New Year in the mountains above Graz in southern Austria. Erich was a slightly older son of a minor Nazi, who had died in the war, emancipating himself from his petit-bourgeois origins without losing his roots. He had received a doctoral degree in law and then had made his way through various counselling jobs with liberals and social democrats all over Europe, but later from his mountains became a unique institution of high-level ghost-writing and of low-level networks of European sub-politics. He tried to connect his friends from the Italian Lotta Continua to build up an alternative European network, much as he later assembled his friends from the Greens, including Petra Kelly, when he became a militant against nuclear power in Austria. But at the same time he wrote texts that were to be published under the name of a 
Dutch commissioner of the European Community, of the progressive Catholic cardinal of Salzburg, or of Austria's Social-Democratic leader, Bruno Kreisky; or, with all his temperament, wit, and patience, he persuaded policy-planners of a social-democratic economic program of taking a more environmental and "glocal" approach. It was only after his sixty-fifth birthday that he became an honorary professor at Klagenfurt. He introduced me, among other things, to the readings of Ivan Illich and René Girard, or debated with me Carl Schmitt or Ernst Jünger, along with the newest leaflets of some Italian revolutionary group from his network of European subpolitics. When I came back from the mountains, where Erich in his most tolerant friendliness had on long walks blown out the dust from my brains, and where I had met extraordinary people among their other guests, I always carried along various incentives of thought and long reading lists, sometimes too long to read.

But getting back to 1971 and the Bonn project, the three of us - I do not know why, but these radiant guys, full of contradictions, connections, and charms, just seemed to me to be so much more attractive than the academic careerists around - combined in writing a dissenting opinion, that was by statute granted as a possibility to all in the project, in which we articulated a critical perspective on the democratic deficit of European integration. In the end our articles, but not our dissenting opinion against Carstens' political summary, were published in the three volumes that resulted from the project. Eberhard Schultz had tried to mediate behind the lines, but could not help, and Löwenthal, whose analytical mind and rhetoric brilliance I adored, even when it turned against me, took it upon himself to explain that, against all promises, no dissenting opinions were to be published, ours being the only one. We then published it, in expanded form, as a long article in a journal that had a far wider circulation than the three volumes of the project could ever reach, but of course it had far less impact. On this occasion, for the first time, I had encountered from up close, much to my disillusionment, the workings of political power in discourse.

\section{Production Collective}

After this apprenticeship in cooperation and dissent, I passed my journeyman's years in the field with a cooperative project that was regarded in the fashion of the day as a "production collective," but that became a basic school of teamwork for me. Still writing my dissertation in 1970 I found, as side notes, two surprises. First, that there had been local working-class liberation committees in Germany, in almost every city, that had regenerated civic life at the grassroots that had been repressed by most Allied authorities (and even more repressed in public memory ever since). Second, that I could, together with a leftist friend in Frankfurt (who later gave up his dissertation and became a professional in anti-authoritarian kindergartens), find a dozen graduate students of history from all over West Germany, who also had found traces of this phenomenon in their own research. We would combine in 1972 to form a working group to recover this repressed experience of working-class initiative. As it turned out, but for three Social Democrats and me, all others came from most of the then fashionable factions of the new Left, usually in bitter struggle against one another, and we debated painstakingly all sorts of leftist interpretations 
of the "Antifa" - (or anti-fascist) committees. But we were also historians devoted to empirical evidence, wanting to make an intervention into public memory and fortunately we also liked, in the pub after days of discussion, to exchange often bizarre stories of the inner workings of various "group authorities" and to share a generous inter-factional humour. After years of research and discussions and after various crises, we had drafts of three-quarters of a big and empirical book. So, Peter Brandt, then probably still with the Trotskyists, later to become my successor at the Open University, and I decided that it was time to edit the stuff and fill in the rest, and he could invite me for a long quiet summer at his mother's dacha in Norway. There we finalised much of our "revolutionary" findings, benefiting from the gracious hospitality of his mother Rut, one of the most charming ladies I ever met, and for reasons of security watched over by the bodyguards of Willy Brandt. The former chancellor was rather laconic at the dinner table, being completely absorbed with writing his memoirs, two years after he had to leave office because the GDR had smuggled a spy into his antechamber. But on occasional walks with us he proved to be a rich and open source of information on all sorts of anti-fascist émigré politics, having the memory of an elephant. After more editing at home together with Ulrich Borsdorf, who somewhat later became the editor of the theoretical monthly of the German trade unions' federation, our book finally saw daylight the next year. It included a dissenting Maoist opinion against the majority interpretation, which had been formulated by my stressing the grassroots and co-operative character of the "Antifas" as well as looking with "rescuing critique" upon this repressed resource of a democratic beginning.

\section{Networking and Initiatives}

Networking among the progressive minority of university institutes of history was a similar experience. We were looking for fellows who were interested in anti-fascist, working-class, women's, peoples' and, more generally, everyday history and found them usually in other minor provincial places such as Bremen, Hanover and some other new university towns. The exceptions to this included an innovative group at the Technical University of Berlin, brought together by Reinhard Rürup and Karin Hausen and including such innovative leftist culturalists as Ludolf Kuchenbuch, whom I later could persuade to become the one professor of "older (meaning ancient and medieval) history" in the world at Hagen; Regina Schulte, who later became my second wife; as well as a group in the élitist Max-Planck-Institute for History at Göttingen, whose outstanding director at the time, Rudolf Vierhaus, a great scholar and a liberal from the Ruhr had, with caring authority, assembled some of the most innovative leftist historians around him, including old friends like Hans Medick and Alf Lüdtke. We exchanged our differentiated views, fostered our didactical programs, in some cases even recruited personnel from each other's resources and most importantly built up a journal, Journal Geschichte, that translated the impulses of L'Histoire for more varied, more critical, more interdisciplinary, illustrated and narrative histories into German. Journal Geschichte had in the late ' 70 s and ' 80 s the widest, if still relatively small, circulation (below 10 000) of all scientific historical journals in Germany. I was among its founders 
together with, among others: the ancient historian and conservative narrativist Christian Meier (later to become President of the German Federation of Historians as well as of the Academy of German Language); the most cheerful medievalist Achatz von Müller, activist of the Federal Conference of Assistants after '68, who gained, with all his knowledge about the Italian Renaissance, the chair of Jacob Burckhardt at Basel; and Irmgard Wilharm, a sincere and progressive fighter for social democratic rationality in modern history. For exactly ten years, I stayed on this rather active and conflictual editorial board, which later included two leading and shrewd gender historians, Karin Hausen and Heide Wunder as well as, when Meier could no longer endure our progressive majority, the ancient historian and an anthropologist of traditional societies all over the world, Jochen Martin.

Such networks of academically established historians were also a backbone of the relatively late reception of the History Workshop movement in their German equivalent, the Geschichtswerkstätten. These relied in the '80s largely on the collective initiative of assistants and research students in history, combining their efforts for an alternative, more critical and more popular public history "from below" with local initiatives of amateurs, mostly from the Left, trade unions and later from the ecological, feminist, regionalist and peace movements in an increasing number of places. Many of them were focused on the discovery of the repressed social and regional history of Nazism. As far as I can remember, I was not a member, but I would give some advice here and there and was very much on their side. For a larger public I defended with others our approaches in a show-down with Hans-Ulrich Wehler, the protagonist of the Bielefeld School of "historical social science" (and ever since a friend in polemics) at a crowded meeting on Alltagsgeschichte at the 1985 biennial conference of the historians' federation in Berlin. I still think that most of his argument against us then was false or at least prejudiced (he turned, with many precautions, to culturalism somewhat later), except for one thing in which he was right: our practices were anathema to historical synthesis.

On the local level, however, I engaged in number of such initiatives, and two of them were symbolically valuable and successful. At the beginning of the '80s, I helped Detlev Peukert and others in rescuing the old synagogue of Essen, once the largest temple in West Germany. Burned down by the Nazis in 1938, restored on the outside after the war, but now housing a museum of industrial design, we had a more decent use in mind: a forum, dedicated to the remembrance of anti-fascist resistance, the victims of Nazi repression and mass murder, and Jewish culture. (Our oral history project of the Ruhr was also housed in this gracious building in its founding years.) At the end of the decade I helped Ulrich Borsdorf, then directing the history museum of the Ruhr, and others to rescue the biggest modernist mine of the '20s from the dangers of demolition. Together with him I wrote a long memorandum in 1987, evaluating its significance for the cultural memory of the region and outlining its possible uses as a combination of museums, joined with workshops of art and entertainment in private-public partnership. I sat on the board of the Bauhütte Zeche Zollverein in the founding years. Local Social Democratic politicians and Karl 
Ganser, the most ingenious networker I ever met, then presiding over the "International Building Exposition" and using it as an instrument for the redevelopment of the remains of coal and steel industry into a more encouraging ambient, had taken over the idea and got it moving. It is still in the making, but the two-thirds that have been realised meanwhile in differing, but similar ways, as we had suggested, are very successful indeed in bringing life and culture into the middle of the closed down mining area and preserving its most impressive symbol of technology and labour.

A much stronger backbone of the dynamics of history "from below" was the biennial Federal Presidential Award German History Pupils Competition (Schülerwettbewerb Deutsche Geschichte um den Preis des Bundespräsidenten). This was a rare and exceedingly successful combination of, one, a Social Democratic initiative to wage a more democratic history by Gustav Heinemann (Federal President since 1969), that had to be taken over by his more conservative successors; two, the private industrial Körber Foundation at Hamburg oriented towards innovation, public responsibility and social resonance; and three, a bunch of historical advisors largely representing a more pluralist edition of our alternative network. This combination spread our mix of recovered alternative traditions, widening interests in socio-cultural, anti-fascist and localist approaches to a history "from below," and the encouragement of popular memory work into virtually every German school. It generated thousands of youthful projects year by year, thereby transforming the uses of local archives, the acceptance of oral history and the resonance of our approaches in the media. I joined the advisory board by the mid-'70s, and later the national jury, and stayed there for some ten years. Of all my experiences with teams and networks, this one was certainly the most successful, and the liberalism of the operating foundation taught me a second lesson in creative teamwork. They wanted advice beyond their prejudices and did not accept ours, but rather forced us time and again into a creative and argumentative group process generating results acceptable to the federal presidents and inspiring to schools all over the country. And, amazingly, most of the time it worked.

\section{"Glocalism" in European and National Cooperations}

Beyond such local, regional and federal lessons of historical networking in memory work, it was in their mixing with national and "international" spheres where I encountered most of its charms and challenges.

When I first started out on a more professional approach to oral history, the impulse had come from somebody else and at first I did not get down to the grassroots, but moved up, up and away. One day in the mid-'70s a friend, Gotthard Scholz (who later became the administrator of one of Germany's Protestant churches, then working in a government department at Bonn), suggested on returning from a visit to the United States that it should be a major task for contemporary historians specialising in the post-war era (like me), to get on record the life stories of those founding fathers of West German democracy who had not published memoirs and were still around. My reaction was a productive hesitation. Even before having a tape recorder, I had 
interviewed numbers of major and minor politicians for my dissertation and our Antifa-project. This experience had left the same mixed feelings with me as with most historians: indispensable as it had been for background knowledge, it usually lacked in detail and accuracy, wherever it could be checked against archival records. Since my first long stay in American archives in 1965, to be repeated in subsequent years, stretching from coast to coast, and to include interviews with numerous political witnesses and contacts with senior colleagues, I respected the efficiency of institutions in the United States. I was impressed with the generosity, vigour, nationalism and relative moralistic sincerity of much of their political and academic élites, with the difference of their popular cultures and the comforts and alienation of their everyday lives and infrastructures. In short: I rather liked America for being so different. Again in strong contrast with many former '68ers (who, not knowing it before, when they struggled against American imperialism, later on identified it, and themselves, with universalism), even nowadays, I think there is a lot to be learned from contacts across the Atlantic. But taken as a whole I never could imagine why, and how, it should become a model for Europe.

With such an attitude in mind I went back in 1975 and toured all major centres of oral history studies and collections from coast to coast, starting in the Butler Library of Columbia University, including all U.S. Presidential archives, and reaching down to various ethnographic and local projects. I wanted to question the interviewers whether, and how, they had overcome the methodological problems with interviewing living memory. Again, I was impressed with the wealth and sincerity of American achievement, but also with its cultural specificity. Coming home I wrote a long report evaluating the knowledge and materials I had gathered, drawing in essence three conclusions. One, the mass production of sub-élite biographies in the form of interviewtranscripts, to be censored by the interviewees, were peculiar to American culture and publicity and should not be followed up on this side of the Atlantic. With the exception that it could be done with full access to the pertinent records, as it was then practised in most Presidential archives with minor survivors from their respective administrations. Two, the use of the interview in populist and educational projects was an interesting tool for reviving and challenging popular traditions, even though its uses were often romantic and naïve. Where most was to be learned, however, was from more professional ethnological and history-from-below projects and their increasingly sophisticated methodology and reasoning about the workings of memory and interaction in the interview situation. Three, given the sharp discontinuities of German history in the twentieth century, we should be less trustful than American optimism with the identity of interviewees and their willingness and ability to testify about certain events and relationships in their past. Therefore, even if we were mainly interested in such a topic, we should, given conditions of German history, avoid thematically-focused interviews and opt for a life-cycle approach, generating much more analysable evidence of the interviewee's formation, surroundings and thinking. 
The next step was to gather information about interviewing practices and projects already done or underway in West Germany, publishing together with Franz Brüggemeier a list of works in progress in 1978 (and again in 1984), as a tool for networking and staging or visiting small workshops to exchange experiences. The next step was to reach out to European neighbours to learn from their approaches and more advanced experiences largely in the fields mentioned in the second point above, but more tinged with European leftist traditions and the rise of a new feminism. In this I profited from my friendships within the History Workshop, then at its peak. It was becoming a real movement in England and spreading over to the continent, where I encountered its translation into French rhetoric and militancy during my year at the Maison des Sciences de l'Homme in Paris in 1978. The best thing however was that in this year a European network of oral historians took shape that I could join to learn and to compose, together with Werner Trapp, a German language reader of the best of its researches and reflections [1980]. After all these preparations, Detlev Peukert, Franz Brüggemeier and I designed our oral history project, "Lebensgeschichte und Sozialkultur im Ruhrgebiet, 1930-60" (abbreviated LUSIR, "Lifestory and Social Culture in the Ruhr"). Having been lucky to get enough funds from the Volkswagen Foundation, we built up a whole new research group whose eight part-time members again turned out to represent a wide variety of former leftist (and future feminist positions). The group included Alexander von Plato, who had just left the dissolving national executive of one of the three existing Maoist parties and was to become (besides a close friend) a very empirical practitioner of oral history and its best networker in Germany over the two decades to come. He built up an institute and archive for biographical inquiries at the Open University and has edited the journal BIOS since the late ' 80 s. From 1980, the LUSIR research group was for a couple of years my next adventure in teamwork and productive pluralism. But since I have contributed reports on the adventure of this project to Paul Thompson's collection of essays Our Common History in English (1982), and on its methodological implications in the last of the three volumes that the group produced, in German (1985), I stop here in my tracks and turn again to the European context.

From 1978 in England onwards I met at least once a year with European (and later on more international) colleagues in oral history in different countries. They had formed an international association, of which I became the German representative in the ' 80 s and its president around 1990. Much to the disappointment of our pioneering and most experienced English member Paul Thompson, a builder of a world empire of oral historians along Robert's Rules of democratic procedure, the confederal structures of this association seem to have been intuitively modelled on those of the EU. I.e., they were utterly undemocratic, but allowed for different national styles to be integrated and proved in the end rather effective and, what is more in and around academia, most of the time pleasurable, friendly, and sometimes even erotic. The core group largely remained who it had been from early on, including a wide variety of characters such as François Bédarida (Paris), a fine diplomatic scholar fighting brilliantly a losing battle for French to be a second lingua franca, but thereby confronting all other languages; Gerhard Botz (Salzburg), 
mediating between Alltagsgeschichte and Historical Social Science; Ron Grele (New York), our cool American leftist, being one of the most experienced in the practice of interviews and in the theoretical reflection on the implications; Philippe Joutard (Aix-en-Provence), brilliant in his insight about much more than contemporary memory, reaching back to the Middle Ages in the Cevennes, but lost with the charm of a little boy as he tried hard to translate his French rhetoric for a somehow English double-dutching audience; Selma Leydesdorff (Amsterdam), our most vivid and practically minded Jewish member; Luisa Passerini (Turin), challenging our headiness by theorizing the meaning of silence within memory in many languages and leading the way from conventional assumptions of the New Left; and Mercedes Vilanova (Barcelona), a down to earth academic mother, insisting on professional standards and no romantic nonsense. And this core group was reaching out to Scandinavia, ranging from the balanced habits of experienced anthropologists to the fascinating "glocal" mission of Sven Lindquist's "Dig where you stand" (Stockholm), and increasingly to Latin America, later Eastern Europe, Turkey and many other parts of the world. Personally I learned at lot within the "glocal" ambient of our association and festival-like conferences. Intellectually I gained most from my evolving friendships with Luisa Passerini and Ron Grele, both in my view being outstanding theoreticians of our field and beyond. From our Essen conference in 1990 on "Memory and Social Change," profiting from the opening of the Soviet world, Irina Sherbakov (Moscow), Jewish, descendant of the Communist International aristocracy, with a strong oppositional impulse, activist of the group "Memorial" that since Gorbachev's glasnost had begun to uncover the history of the Gulag and Stalinist repression, and with her breathtaking analyses of women in the Gulag, became a star (and for me a close friend ever since).

I left the association and the field (after an unusually long period of fifteen years) in the early ' 90 s, having become somehow notorious because the German member was asked more than once to give at the end an evaluation of the conference and the state of the profession. Of course, I was flattered by this impossible task, to have a final word in passing, and my agitation was only somewhat calmed by the fact that most of the participants, at this time, were already packing. (At Essen, Karin Hartewig and I issued instead a special number of BIOS with collected essays on the state of the profession in many countries.) But otherwise I have been a fan of these conferences. Each of the early and/or senior members of our association was supposed to build up a network of information within her or his country. This loose structure proved to be quite efficient in assembling us all, the majority of the more professional oral history community of an open-minded Europe, by various hundreds, at biennial conferences each time in a different place in Europe. Without a stable organisation, the chair rotated every second year to the country where people were willing and able to shoulder the load of organisation and find at least some funds. Dozens and hundreds of proposals from various cultures had to be evaluated and grouped; we carved out little, maybe too little. And the problem of languages stayed with us all the time, because there is no real lingua franca, but even more because oral evidence is very difficult to translate indeed. And last but not least, because a superb interviewer at the grassroots and 
sophisticated interpreter of localised culture can, but often enough will not be, a brilliant contributor to international discourse in foreign languages. But in the end we had meetings that stand out for their intercultural exchange, their friendly criticisms, their stimulating theoretical debates, and for their placement within popular festivities, generating friendship and intellectual interest beyond boundaries. We learned a lot about national peculiarities in the experience of similar social groups and got more and more acquainted with the features of private and collective memory and with its silences.

\section{A Special Connection to Israel}

Oral history and memory work also brought me back to Israel in the late ' 80 s. To relate to the nations most victimised by Nazi rule had been a deep impulse within me from my student days, so I had been among the first groups of students from Germany working for a summer in an Israeli kibbutz (as well as, somewhat later, travelling to and establishing contacts within Poland). The summer spent in a strongly Zionist Haganah kibbutz in a Palestinian district under military rule on the Jordanian border, came during the intermission of the Eichmann trial in 1961 and became the first really complex experience I had abroad, stimulating a deep interest in and attachment to the Jewish world and, at the same time, a more realistic appreciation of what it meant to be German. Adding to this complexity, I had travelled together with an acquaintance from the networks of the Junge Presse, Christane Vonberg, later to become my first wife and a judge, whose bourgeois parents had kept their relations with Jewish friends, even when the latter had to emigrate to Palestine in the '30s and had remained in Tel Aviv very German Jekkes indeed. So we had a second anchoring point for some additional weeks and got introduced to the pluralism within the Jewish world, the complexities of Israel, and to an emotional base of our later marriage. Some time later I went down to the Near East again, this time on an archaeological trip with theologians, touring the neighbouring Arab countries as well as Israel, and getting an even deeper introduction into the political and cultural problems of the region. But since the wars of 1967 and 1973 I had not returned, because all of the increasing number of German study groups then travelling to Israel were, as part of the standard program, led through the newly occupied areas, and I was reluctant to let myself get forced into decisions between my heart and my brains, my attachment to Israel, my feeling of some sort of German responsibility for the region as a whole, and my complete helplessness.

In the meantime, however, I had established, through oral history and various other working relationships, close contacts with many Jewish colleagues some of which evolved into friendships, like those with Charles Maier in the United States, Raphael Samuel in England, Michael Pollak, an Austrian in Paris doing beautiful memory studies with French survivors of the Holocaust, Micha Brumlik, with whom I tried to direct a research project on the Nazi persecution of the Gypsies, and Dan Diner, a Frankfurt leftist of Polish origin, then transforming into a Jewish authority, shuttling between Israel and Germany, and becoming a major intellectual stimulant and challenge for me since I first heard him speaking about the remembrance of the Holocaust in the early ' 80 s. 
But in the second part of the '80s, I was invited one day by Saul Friedländer to give a talk on our oral history projects in the Ruhr at Tel Aviv University, a pull strong enough to wipe away immediately all of my somehow silly political hesitations, taking myself much too seriously. I chose to talk from notes about strange German love affairs during and after the war, and the result was twofold. For one, across his scepticism of Alltagsgeschichte, a friendly and respectful relationship was established with this thoughtful and beautiful scholar, with whom I later directed a German-Israeli research project about issues of public memory in both countries, with various of my closest collaborators being invited as fellows to Tel Aviv University. The other was more immediate, because on the very night of my talk one of the colleagues in the audience - a sabre and survivors' daughter and strong Zionist, who had always avoided contacts with Germans, and was then doing Holocaust research on her father's region in Poland - and I fell in love in such a way, that during the following months our amour fou challenged all other loyalties. And on my second visit, after a couple of weeks, we made a beautiful trip together to the Dead Sea - right across the occupied areas. But after some time of intensive exchange we became wise enough to cut our explosive affair and transform it into something unique, a distance of life and a deep and most trustful attachment at the same time. When at the end of the '90s during my job as government advisor on forced labour compensation I was looking for advice and contacts in Israel, Sara Bender volunteered as my most thoughtful counsel and, with all her knowledge and charms, opened for me within days some of the most important doors to survivors' experience, thought, and politics.

\section{Beyond the National Border Inside}

But "international relations" of Germans in the late Cold War could also be "national" and when I was first invited to an international conference on anti-fascism in the GDR in 1984, one of the greatest political adventures of my life began. There I met a partner in critical collaboration, Olaf Groehler, deputy director of the huge Institute for German History in the Academy of Sciences of the GDR. Networking could, if in a much more sceptical and complicated, diplomatic and cautious way, also work across the great divide. In the years to come we staged workshops with contemporary historians from the two Germanies, hitherto unknown, on alternatives in and against the Cold War, on both sides of the border at Hagen and in Thuringia, near Frankfurt in the West and near Berlin in the East. During a sabbatical, I was invited as some sort of fellow with the historians of the Academy. Finally, after a lot of academic and political manoeuvring, I gained an extremely rare, if not the only, permission to be granted personally by the head of state Erich Honecker to do, together with Dorothee Wierling and Alexander von Plato, oral history research in three industrial centres of the GDR as well as get permanent visas to move across the inner German border for almost a year in 1987. I have shared the adventures and lessons of this project extensively in the introduction of our book, including interpretations of thirty of our 150 life-cycle interviews, Die volkseigene Erfahrung [1991, the title being untranslatable, literally "the people's own experience," but also that of nationalised industry], and I cannot elaborate here. 
Two experiences, however, seem to be noteworthy within our context here: For one, that against our expectations, from the mid-'80s onward, networking and memory work became possible to a certain extent beyond the barriers of the Cold War, if one tried hard enough. Two, we could diagnose from our interview evidence, that within the GDR a socialist value pattern had not really taken roots. The cohesion of state-socialism had been due, next to the presence of Soviet forces, largely to an integrative system of social mobility among the now older generations, that was not transferable to the younger ones. When I was a fellow at the West Berlin Wissenschaftskolleg in the following year, I gave a paper on my first interpretations [published in the first issue of BIOS 1988, available also in English in Alf Lüdtke's reader on Alltagsgeschichte 1995], concluding that a fundamental cultural crisis was on the agenda of the GDR. When the outburst of popular struggle for civil liberties among the younger generations (and massive illegal emigration of even younger ones to the West) brought the regime down two years later, it paved the way for the withdrawal of the Soviets and finally the incorporation of East Germany into the Federal Republic. We were of course very much moved by the events, but somehow less surprised than many other contemporaries. More, I was struck by the virtues and vices of our prognosis, very lonely as it was at the time of Honecker's visit to Bonn and a general appreciation of the tiny GDR as the most stable and tenth largest industrial power in the world.

Obviously our general diagnosis of a potential for a major crisis had been right, but we had not envisaged the interplay of the socio-cultural with the political and with international power. I had not taken into consideration the inner workings of the Soviet Union, of which I then knew very little, and simply could not imagine Gorbachev's final withdrawal, to provide a more precise forecast. Even before "culture" became the new fashionable paradigm among historians, I had to learn that culturalism was not enough. So the question of how to relate the dimensions of the socio-cultural in history with international power structures has become a challenge ever since. The methodological difficulty of this relationship may be the true reason why I am so behind with my history of Germany in the second half of the twentieth century.

\section{Advanced Studies}

Speaking however of networking and administration, in early 1989, to my surprise, I got commissioned to found one of the major centres for advanced cultural studies in Central Europe, after Jürgen Kocka on close observation of the administrative conditions, had declined the job. I took it as a fantastic opportunity; as I later found out, he clearly is the better administrator. Nevertheless, six months later, and all within the space of five weeks: my second daughter was born; the new Institute, already staffed with two co-directors and a first group of fellows, was opened by the Minister President of Northrhine-Westfalia, Johannes Rau, with all the notables and media around; and the Berlin Wall was opened. Six weeks later I celebrated my fiftieth birthday amidst family and friends. And again six weeks later, a wild thunderstorm picked the biggest tree near our little house in the countryside and threw it on our roof, under which Regina Schulte and I were working and the baby was sleeping, crushing almost a third of the cottage, including all 
philosophical or otherwise theoretical shelves of my library, but leaving the three of us unharmed. There is a certain luck about my life. I knew from my former fellowships in Oxford, Paris, and both Berlins that advanced studies do not always go together with quietness, concentration, and emotional stability, but when I had to organise them myself, the amount of motion, emotions, and ambient noise was somewhat unusual.

The purpose and profile of the institute was not really decided when I took over, and from the start I tried to avoid it becoming either a think tank for the government or an honorary repository for over-established academics. I felt that a centre for advanced studies should first of all contribute to the encouragement and stimulation of intellectual life in the university system at large. It should do this by being a meeting place for productive talents from all specialised sectors of the arts and social sciences, where they could open their minds and disciplinary routines, learn from one another in a challenging and sociable atmosphere, and find a breathing space to reflect the shortcomings of their often isolated and overspecialised practice as well as confront major issues of contemporary cultural transformation in a cooperative way. With this encouragement and training in exchange, and hopefully some fruitful ideas and new networks of reference, they should then go back to their place and radiate this spirit within and beyond their departments. The great chance of such an institute was not to be a retreat for a bunch of élite academics to find a new-world formula, but to liberate in a continuous process, within the enormously overgrown and over-administered university system, the great dormant potentials for intellectual creativity, cooperation, and responsibility.

In planning I had placed my emphasis among other features on three points. One, we should not try to virtualise a "school" of thinking about culture, but accept the diversity of unmastered problematics of our time as well as different approaches to their perceptions, and invite their tensions into the study groups of our fellows and their interplay, to create a challenging climate of sensible sensitivity. And everything should be temporary: fellowships usually for a year and our study groups (on art, media and power; gender and public space; ecological philosophy and intellectual history; theories of memory; and socio-cultural resources of old industrial regions for transformation) for five years. Two, we should invite women and men alike to confront these challenges (instead of carving out women from élite institutions or providing them with a limited playground for feminist specialities). And indeed we ended up as the one academic institution then where the male majority was slim, and gendered perceptions of all matters were present in almost every discussion. In my view that was a big advance: exertion, productivity and charms being equally distributed. Again to vivify and normalise intellectual exchange we should invite, in addition to well established academics, younger promising fellows, even though their selection may cause legitimation problems, given academic envy; but in the first years we were lucky since most of our un-established fellows got established very soon thereafter. Three, and this point was added in the winter of 1989/90, we should not limit ourselves to invite, as it was fashionable in the early ' 90 s, some intellectuals from the East to the West. Rather, we should open up a 
supportive centre in Leipzig, with finances for fellowships and workshops at least during the period of transition, to provide intellectuals there a breathing space in the midst of dramatic change in order to develop their own experience and at the same time network their way from home into newly opened-up intellectual worlds.

I could sell such guidelines more easily to academia than to the politicians around, with the exception of my immediate superior Anke Brunn, then Social Democratic minister for science and research in the state, who listened carefully and defended our approach more than once. But most others were expecting quick results, broad publicity, or at least names they knew from television. Some new and decisive bureaucrats, having started on the party line, pressed for major research programs and more control. They made our autonomy more and more difficult in day-to-day red tape and finally let us down by blocking the last slice of money for the promised reconstruction of an old mill that should have housed the centre after three years of planning a beautiful symbol and a hospitable place. Nevertheless, the institute's take-off in terms of intellectual activity, sociability and respect was fast. This was especially due to my co-directors, heading small study-groups: Martin Warnke, an innovative art historian of great standing and even better judgement and a very amiable and generous person; Sigrid Weigel, a younger, well read, highly sophisticated and still very political feminist literary critic; and Klaus Meyer-Abich, a physicist and philosopher with political practice and now an uncompromising ecologist of almost fundamentalist persuasions. When Warnke said farewell - fed up even before I with the outreach, instead of turn-out, of the bureaucracy above us - he was replaced by Detlev Hofmann, art historian again, a great debater, full of energy and laughter and famed for his innovative perceptions of museology and memorial sites. Later, we added Gertrud Koch, covering media, a well-known specialist of film history and critique with rich international connections, a sharp eye and a dry wit. All of them had a fine hand in picking promising people for invitation, but also enough tolerance to endure the tensions between our approaches and participate actively in discussions beyond their fields.

Besides the work in the more specialised study-groups, we assembled all fellows to a jour fix on Monday afternoon, including a lecture by one of the fellows, often long interdisciplinary discussions, and a buffet well into the night. We were partly housed in an old town hall of one of the boroughs of Essen, charming but too small to give room to the thirty or so academics on our payroll. However, it had a stately hall for our exchanges that quickly became an attractive place for meetings even from the outside. We and groups of other fellows staged many workshops and conferences there, sometimes two a month, so that our climate and level of debate could radiate. I also liked my monthly travels to Leipzig to back up Dorothee Wierling, heading our extramural outpost there in parts of a dilapidated villa, in the selection of fellows and participating in her very lively workshops. On the other hand I had also (and again) to face my limits as an administrator, especially my lacking sense for public relations and lacking ability either to handle the wider political machinery or to get away from it, which I would have preferred. 
The emancipation of the institute from being part of the state administration and its transformation into a foundation never came, though it had been envisaged from early on. From the start I had not wanted to stay in such a managerial capacity for the rest of my life, but designed the centre to be only a temporary place for every academic, including its directors. But finally I withdrew before the end of my contract, in order to go east and encounter my limits in networking.

Let me leave it at that. The last chapter of my institutional anci extramural experiences is still going on, and stories are more worthwhile told when they have some sort of an end and are not squeezed between the restraints of an ongoing practice.

\section{3 Hidden Agenda?}

Amid the diversity of my published work there are recurrent themes, and through the discontinuity of my institutional engagements and of my increasing lust for networking and intellectual adventure runs a pattern of reactions, both of which seem to be beyond my control.

\section{Family Patterns}

Speaking of these patterns first, it should be evident from my sketches that it was never easy for me to accept paternal authority. In my early studies I met with a number of impressive father figures, but I did not really get attached to one of them. I was not used to such attachments and mistrusted them, feeling more as a guest in schools of thought and in institutions, where eminence was always male. However, there also was a fascination with such institutions and in my professional life I accepted them as frameworks of practice, but also tried to transform them, to soften their authority and to make them more open, integrative, and caring. And when I got into paternal roles myself (and there were many chances), I usually stayed only for a couple of years and acted more like a counsel or - to put it again into familial terms - as a brother or uncle or friend. In short, I was at odds with my own authority and could not provide stability to others over a long-term perspective. Neither could I accept my place in hierarchies, getting angry and imprudent as soon I felt somebody exerting institutional power over me and those for whom I felt responsible. After some battles lost, I usually drew the line, leaving them not very responsibly alone. Looking back I think I really was an expert on compromise, but very seldom with superiors.

On the other hand, you will have seen that this problematic "l" was, within my growing engagement in teams and networks, more and more substituted by changing or associating varieties of "We." This communal feeling came late into my life, and growing older, I felt younger. It took me decades to get a more balanced appreciation of my age. Somehow I seem to have missed the stages of brothers and sisters, of close friendship and juvenile hordes, acting out their aggressions, in my childhood and youth. When I once read a line by Henry Miller, that his youth had begun late (I think at the age of forty), it rang a familiar bell. So I got fascinated with comradeship and adventure, when I already was a father, privately and in institutional roles, and went on my travels. Or took up for instance the familiar " $D u$," that I had very seldom used when I was a 
student and even less in 1968, in most of our teams thereafter. And I liked it a lot when finally there appeared women within these networks and teams. Most of the time I felt much more at ease with them than with many of my own sex, in work, discussions, and elsewhere. Is it not crazy to describe one's professional life in terms of anachronistic substitutions of family and youth?

\section{Recurrent Theme}

Speaking of themes, something always seems to bring me back to the consequences and inheritances of Nazism (rather than to Nazism as a historical subject matter itself). When after my first three publications in this field, I definitely wanted to leave it and began research on urbanism and social control in the nineteenth century. That book was never written; instead we completed another book on anti-fascist committees, and we did it as a team. When I tried to import oral history into German academia, there were many fields to probe methodically. Workers' experiences were an obvious choice, given that I worked in the Ruhr and was engaged with trade unions, and that more empirical approaches to the working class were clearly on the agenda in the decade after 1968. But what did we do in our oral history projects, working again in teams? We concentrated on the time-span from the '20s to the '60s, both in the Ruhr and in the East, to find out in what ways the experience of Nazism and the war had formed the perceptive structures of post-war workers, their adaptability to given societal changes, and their individualism. When I moved to Jena, I clearly wanted to form a research initiative around the cultural history of infrastructures, Alltagsgeschichte from the top down so to speak. We discussed this idea a lot in Jena. But what did I actually do in the mid-'90s? Projects about the camps of Buchenwald and their memory. And in 1998, when I finally got a year off from teaching to write in Florence an essay on the history of the future in twentieth century Europe as a prologue to my interests in infrastructures and to at least find a starting point for my synthesis on post-war Germany? I skipped both projects when I was asked to consult the Federal Chancellery in the making of a policy for the compensation of Nazi forced labour. I almost completely concentrated on this challenge for some two years.

This involuntary recurrence of one big theme, transforming most of my other historical departures or even ruining them, can only be explained to a certain extent. This theme was always and increasingly present in the German public in the '70s and ' 80 s and remained so, to the surprise of most observers, after 1990. My eagerness to be drawn into institutional responsibility, at least for a while, and to find my place and friends in collective networks and interventions made me, as an historian, susceptible to the workings of public memory. And after all, I was specialised in this field from early on. But this sort of rational explanation is insufficient. There seems to have been a deeper layer of the private and public conditioning of my subjectivity, responsible for the major decisions regarding the priorities and approaches of my work - or should I better speak of intuitions that "made up my mind"? I guess, at least within my age cohort, between the famous "sceptical" and '68 generations, I am not the only one who lacks clear cultural references for his behaviour, for the discontinuity of his rather industrious engagements and the continuous 
recurrence of themes and patterns beyond his control. And who in advanced years is still undecided whether this source of productivity is a vice or a virtue, a torture or a gift. Or is it a more general feature of specialists of contemporary history, that - not wholly, but in the last instance - they produce involuntary histories, rooted in unconscious layers of their own memories and co-authored by public memory?

\section{Memory and History: Conceptual Intervention}

Despite all the recent cultural and biological advances towards a theory of human memory, we still have no real understanding of its workings, of the interplay of culture and nature, and thus of the individual and the collective. Memory is still largely a metaphor. But one thing is sure: individual and collective memory is a fundamental human property, to be observed cross culturally at all times and everywhere, whereas History is not. History is a relatively late acquisition in the process of European civilisation. At least as long as History is understood as a field of inquiry that has to do with research into the past in search of a past reality (that of course, as such, is gone) and with thought about secular processes and development. On the other hand, all other ways of transmitting knowledge about the past, usually flowing with unreasonable truths and creating feelings of belonging, were (and are) central to cultural memory. From the first story-tellers and chroniclers onwards through more elaborated forms of legend and traditions, cultural memory is preserved and prolonged, proceeding well into the contemporary world with its negotiated school curricula and less negotiated political propaganda, its selective preservation of cultural heritage and its constructions of memorial sites, its imagery of well designed corporate (or whatever) identities and its invented traditions, its media, museology and publicity. In cultural memory there are no criteria, whether the message is good or bad, right or wrong, its main criterion being whether a message is believed without reasoning or need of proof. In short: the magic of traditions and more recently constructed versions of collective memory is to be found in a virtual truth, in the efficiency of its transmitting forms and in the emotions of attachment it can arouse.

What was new about History was that historians tried to step out of traditions and question their truths. They declined the chronicler's job of simply prolonging traditions for the sake of the recent past or selecting portions of traditional knowledge about the past as telling examples for the present, as the slogan historia magistra vitae had suggested for ages. On the contrary, they turned around in search of evidence for more accurate stories about past reality, allowing for a critical evaluation of traditions. They relativised their acceptance in the present by allocating the currency of their truths to former times and produced - by situating the more accurately reconstructed stories within - conceptual constructions of progress, development or process. History is not telling truths; rather, it reaches out to get more accurate knowledge about a past that is both our only field of experience and largely gone, except for its imprints. History is a process of recollecting, approaching an unattainable past, that has left only scarce traces. For that reason it is always a debatable attempt to construe explanations that might make sense of its remnants. 
Most of this is well known, and I reiterate it here only because of the following. Within the rising memory boom among cultural studies during the last two decades, a particular dichotomy has been established between memory and history, one that I find unsuitable for contemporary history and maybe even fundamentally misleading. In this dichotomy memory is associated with space, images, emotions, ritual, associative interaction, values, and "traditional societies," a comprehensive label for everything which is not modern or, as Peter Laslett once called it, the "world we have lost." History, however, is associated with time, texts, rationality, construction, individualism, relativism and "modernity," a label for social and cultural processes that began in the eighteenth century but only became "true" and overriding in the twentieth. I find no fault with the first several particles in the two chains of this ideal type; on the contrary, these juxtapositions are to the point and instructive. I find it rather disturbing, however, that the two chains are placed on the same level and in different times.

Memory is a much wider and more general concept than history and contains a far wider set of individual and cultural practices. And history has by no means done away with memory but is a specifically modern practice within the cultural struggle about the past, with all sorts of memory-dimensions. Old and new traditions, symbols, images, lieux de mémoire, recollections, and emotions in modern society, strategically as well as involuntarily, are produced and reproduced every day in more diversified and pluralistic ways. Historical practice is on closer observation far from exempt from the emotional and associative impact of memory, whether deeply inscribed in the historians' more or less conscious motivations, in the formation of the institutional and intellectual frameworks of their activities, or in the cultural shaping of the publics in and to which they are linked and relate. The imagination and rhetoric of their practice are dependent on styles of narrative and paradigms of thought from the archives of cultural memory. And their results are quite often used, abused, or even produced as stuff to foster or invent what people used to call traditions, values and feelings of belonging to specific collectivities: in short, the cultural formation of peculiarities, that many now call "identities," which is the domain of memory rather than history.

We know by now that memory is not just an envelope for cultural practices of traditional societies, but it is beginning to get a history of its own. Recent research has enlarged our knowledge of the roots and mainstream of European notions of memory and techniques of memorising since ancient times, elabourating on such beautiful prior discoveries of mnemotechniques such as Frances Yates' Art of Memory. Taken together it has shown that the prevailing understanding of both individual and cultural memory was oriented towards the future. The basic question was how to keep something in mind for tomorrow or, by instituting symbols and rituals, to be reminded in ages to come and keep handing down truths and values into posterity. The turning point (or Achsenzeit) of this history of memory, however, is not the intellectual dawn of modernity in the late eighteenth century, but its high noon around and after the turn of the twentieth century. Intellectuals with a foreboding of its destructive potentials - Bergson, Freud, 
Proust, Warburg, or Benjamin (all assimilates of Jewish origin) - launched, each in his own way of fusing the dialectic of Enlightenment and Romanticism, another understanding of a "layered memory" and suggested very different uses and techniques of recollection. Their understanding of recollecting did not relate to a former will, not to be forgotten, or to the power to find an efficient way to be remembered, but did relate to something forgotten and still latently and involuntarily at work. They detected in memory - and more precisely in its hidden, repressed or preconscious layers - a latent resource of redemption and liberation and suggested new, essentially emotional (intuitive, meditative, interactionist, associative) ways of remembering backwards into one's past rather than following the direction of established traditions towards the future. The traces to be followed on these voyages of discovery backwards ("into the inner Africa" as Freud put it; or where "Origin is the goal," a motto of Benjamin taken from Karl Kraus' The Last Days of Humanity) were observations and feelings about what is unintegrated in established traditions and conventions of individual and collective selves.

These innovations, which have become so influential as a counter-movement within Western civilisation during the second half of the twentieth century, resemble in many ways the turn of History against traditional memory and can be seen as a second stage of historicism. This time it began to reach more effectively down to the individual and into collective emotions and desires covered and repressed by the overriding assumptions of development and progress, which History had also constructed as rationalisations against traditional memory and transformed into hegemonic traditions. Remembering now included the dismembering and questioning of the most powerful new traditions of modernity like the progress of civilisation, the collective identity of nations, or the assumption of an autonomous ego, all well established in modern memory. On the other hand, from the early twentieth century the traditional functions of memory also became modernised and theorised, its dimensions of individual learning later to be rationalised and instrumentalised by behaviourism, along with its dimension of cultural stabilisation and reproduction. Halbwachs, in utter opposition to Bergson's and Freud's conceptions of recollection, may have overdone his point, that there is nothing worthwhile in individual memory and all remembering is nothing but reconstructing from social context. In the workings of collective and cultural memory, however, he was much more precise when unmasking social constructivism as its backbone as well as its occupation of holy sites and public spaces to be largely immune from alternative recollections and historical argument. Whereas he had turned this critique against the cultural totalitarianism of Hitler and Stalin, half a century later many in his tracks lament what they see as a loss of collective memory in modernity. They feel free to fill this gap with social constructs about the past in symbolic forms, if they can.

Thus we are left with two ways of memory in the contemporary world: one transmitting unreasonable truth and feelings of loyalty to the future, based on power, acceptability and symbolic forms, and one recollecting in the opposite direction what has been banned from consciousness and established traditions and why. The latter is a much more fragile effort, based 
on close observation, on intuitions in reading traces, and on diffuse desires. Recollection however can strengthen the deconstruction of the powerful and imaginative layers of memory that are reproduced everywhere and everyday. Deconstruction does not mean destruction; that would be a childish fantasy of power. It means, however, an important step in quality: it may ban the magic of the social constructions of memory, as if they were self-understood, whereas the constructions themselves remain. But the challenge may transform them into something more open to debate and reconstruction. With historical practices it is similar, once History had turned as a recollecting initiative against the traditions of memory (religious, dynastic and others). Either it could modify those traditions little by little, or it had to build up or foster huge intellectual constructions about development, progress, collective identities and what not, far beyond their empirical findings, to give these findings a meaning beyond the critique of traditions and incorporate them into coherent but unreasonable truths, to be handed down to posterity. And there we are. The reaching out of new waves of historical research into forgotten micro-cultures and even into the layers of individual memory can ban, or at least irritate, the magic of overpowering assumptions and constructions in present cultures about History that have been taken for granted too long. It can transform them into preliminary outlines to organise and synthesise knowledge, open to debate and change. The powerful imagery of memory will still be there, and be it on the TV-screen. But the belief in it becomes more selective, and, within limits, the content of memory can be corrected.

It no longer sounds sensible to me to wait for or aim at a big theory to arrive for the integration of the recollected and, assuming we had one and could agree on it, make the same mistake of History all over again. Historical practices of recollection begin with and against memories and traditions, that are by now usually invigorated by prevailing assumptions and interpretations of History. They end up challenging them, trying to get integrated into memory, changing it a little, or by being lost again. Therefore they are more diversified, more linked to and in struggle with collective memories. They bring in common people, to study them as media of the memories of their respective cultures to be sure, but also to invite their cooperation in search of the forgotten and repressed. The practice of such partnerships in Oral History is difficult in various ways. A life-cycle interview reaches into intimacy in public. The exchange is unequal. And the interactive process of recollection touches various layers of memory thus generating a diversity of genres of constructions, of legend, of reminiscences, stories and images, often looking like a puzzle in fragments, many of them no longer available. But often they produce a sort of evidence that may not only lead to a historical understanding (rather than a psychological analysis) of the person's hidden agenda, but also unearth textures between the public and the private and their evolution over time, generating questions well beyond the individual for the interpretation of larger groups and cultures. In the end, oral history produces questions, rather than answers, that spill over into other fields of historical interpretation and mediate between diverse dimensions of memory and history. 


\section{In Search of Textures Lost: From the Historian's Laboratory for Recollections}

As a somewhat extended closing of my fragmented substitutes for an ego-histoire I now want to give an example: how the private and the public, constructions, narratives and more or less integrated little scenes interact in the formation of a life-story in most recollective interviews, with the possible exception that in my example the interviewer and the interviewee are the same person, me. I should warn, that such a closing, with but a small extract, will need some patience. In our oral history projects we usually divided our interviews into three parts. First, we gave the interviewees a chance to tell about their life as they saw fit, with as little interfering as possible from our side. Second, we put questions into the loopholes of this public narrative, trying to change the track of memory by asking, for instance, career-driven men about their childhood or their mother, or by confronting women, who had told everything about their families, with political queries like "Did you ever personally see Hitler?", "How do you remember your first encounter with allied soldiers?", or in the GDR, "Where were you on June 17, 1953?" Questions that we wanted to put to all of our interviewees in some way, anyhow. In the third section, usually in a second meeting after we had listened to the tapes of the first, we followed this up, tried to clarify contradictions and then pose a number of questions about the interviewee's work, their politics, their kin and their social environments at various stages of life from a questionnaire. Even though we were always open to new associations and new stories, this third stage was mainly oriented to generating data that we could use for interpretative and comparative purposes, and also as corroborating evidence.

Now, I shall certainly spare you this third laborious stage and skip the first. As an academic before an academic, presenting his persona (Latin for "mask") for public uses, I would have offered a short version of my professional curriculum vitae, most of which data you already know from the prior sections of this paper. And for sure I would not have raised the questions at the beginning of such an interview that I associated in my reflections with these data earlier on. So let us turn to section two and just ask for our example and for a start: "Where do you come from? What do you remember first, thinking of your childhood?"

My first reaction would be to propose some of the essential preconditions of and before my birth, i.e. they would be drawn from family legend. In regard to the first question, I would offer a construction and a constructed narrative pieced together from various genres of narration of memory, of which, however, I have only few reminiscences of my own. More of these would enter when in the end I touch the second question.

\section{1 Construction and Legend}

The construction that I would advance first obviously is designed to explain my liberalism, and my need and strength for interventions, evasiveness and for keeping my spaces of manoeuvre open. I would underline that I come from a very mixed family background with conflicting dynamics in the long run, a family at the crossroads, so to speak. 


\section{Rise and Decay}

My father's family line was Protestant petty-bourgeois in Swabia, beginning as agricultural hands and their bitter struggle for a living and a place in society, then moving upwards, from elementary school teachers to the brewery "cashier" (i.e. today's "financial director") who was a lover of strict discipline and also my grandfather (long dead before my birth). He was married to a big and warm mom of similar Protestant background, and they had four children: a daughter (who married a non-commissioned officer) and three sons, whose varied social achievement counted enough, even though all of them became minor Nazis. The eldest was a fan of motorbikes in his youth, and for us kids later seemed to be an amiable and almost stately figure; however, he never got beyond driving big Mercedes limousines for more or less important bankers. The youngest had entrepreneurial spirit and became a small-scale industrialist, first founding a German base for a minor American multinational, then building airports for the Luftwaffe in occupied Europe and later on combining both experiences by working hard for his own firm in the building industry, drawing on American patents and German talents for improvisation, escaped from the East. My father was in the middle and was destined, because he was practical and because his parents were down to earth, to become a building engineer. But he was impractical enough to run off to become, after some unachieved studies, a graphic designer. Fascinated by modern machinery and with his gift for quick and accurate drawing, later to be supplemented by photography, he specialised in publicity for technical products like tools and cars as well as, after the '50s, more successfully in the design of industrial exhibitions and fairs.

On the other hand, my mother came from an established bourgeois family in the Rhine, with even some radical roots from the time the French Revolution had bordered the Rhine, but later on breeding lawyers and entrepreneurs, occasionally even taking in a daughter from the landed aristocracy. They were liberal and Catholic, looked generous and joyful yet seemed to be on the edge of decay, one of them heading for bankruptcy. Her father had been moderately successful as a private banker in Stuttgart, but died early during World War I, and his fortunes almost completely melted away in the hyper-inflation of 1923. Yet her mother, a strong willed and witty daughter of a judge from Mainz, brought both of her daughters to academic study, the first one even to a doctorate in literature, becoming a very Catholic Fräulein teaching languages in high-schools, and the second to be assistant at a modernist academy of art and design in Stuttgart. In her youth my mother represented what the Nazis soon were attacking as Salonbolschewismus; about her style it may suffice to say that one of her early abstract paintings was selected for a model house of Le Corbusier in 1928. However, as soon as she was accepted as Meisterschüler at the Bauhaus and more particularly by Paul Klee, she missed her chances of becoming a real painter by falling in love with a charming sportsman, who was a few years younger and then still among the students of her school. She had a lively temperament and radiated warmth and wit, but due to a heart defect she had been a rather fat girl in her youth, which may have made her even more defenceless against the advances of this good-looking guy, who was also a great tango dancer, then. 


\section{Family Romance and Seizure of Power}

Instead of moving to Dessau, she stayed in Stuttgart and founded together with him an atelier for advertising art in the modernist style of my mother and with the technical talents of my father just at the onset of the depression. The partners were both wearing trousers and cutting their hair as males at the time, with he calling her "Peter" ever since (whereas she has always signed her paintings with "Amo," a version of the initials of her maiden name, but also alluding to the Latin "I love"). They had a hard, though obviously joyful and adventurous time getting the studio established and making ends meet, and in 1932 they married. In that year, my father also got acquainted with the Storm Troopers, being detailed to an "artist's storm," and joined the Nazi Party. Being otherwise disinterested in politics, he never advanced beyond membership or held any office, but he obviously had to stress his masculinity, liked camaraderie and made useful acquaintances. From the following year on, this greatly paved the way of the atelier and changed in stages its style and appearance. Even though my mother was still doing most of the designing, my father seized power by controlling the public relations of the atelier, which finally appeared under his name alone. He demanded of his wife that she cut her relationships with Jews (one of her closest girlfriends and colleagues from the academy had been a jewel designer from a wealthy Jewish family in the Rhineland, who later managed to emigrate to America), and reluctantly she obeyed. The completely apolitical Salonbolschewist was further silenced when she became pregnant in the summer of 1933, giving birth to my sister and then to my brother within the next years. After this she reappeared as a kitschy illustrator of children's books as well as a designer of figurative decorations that stylised gender-roles in a sweetish romanticism. They were so acceptable in fact that one of the decorations even seems to have been designed, shortly before the war, as wooden inlays in the new country house of a Nazi Gauleiter. It was in the days of this new harmony that I was implanted into the consenting occupied areas of my family, at the crossroads - and as a latecomer. Procreated in spring 1939, was I to be a product of false confidence in victory, or just of a rather strange, but life-long love affair?

\section{Nomen est Omen}

By the way, even though my mother was Catholic, excommunicated for marrying a Protestant, and my father was completely disinterested in religion, I was to be baptised as a Protestant. This was probably a trace of the influences of my grandmothers, both quite pious in different Churches, and parental power in choosing between them. My Christian name was borrowed from the dearest brother of my grandfather, the Catholic banker, in an abridged form, that was trendy then (Dirk, a similarly trendy and germanizing abbreviation of the banker's name Theodor being the alternative). And in contrast to my sister and brother a second name was added, that of my father. One of the employees of my father, a nice and most vivid Fräulein, was to become my godmother. And as godfather a local industrialist was chosen, an earlier member of my father's "artist-storm troop" who had been instrumental in the establishment of the atelier by placing all of his advertising in the hands of my father. Even my mother found my brown-shirt godfather a cheerful guy. I cannot remember having met him: he committed suicide in 1945. 


\section{2 The Composition of Narratives}

The second general reaction to questions about my early formation would be a bit less constructed from the very subjective evaluation of family legend, the narrative increasingly relying on selections from my own recollections, that set in almost exactly with the end of the war. The basic theme of this second reaction surely would be that I did not get to know my father until I was more than eleven years old, and that in the meantime I passed my childhood in an almost completely female world.

\section{Males Lost and Female Authority: My Maternal Nest}

Four months after my father had been recruited to the Wehrmacht, then conquering Poland, I was born in Christmas 1939. Later he moved (as a driver, a cartographer, finally as a medical orderly) to France, to Belorussia and Ukraine. I do not remember his rare presence when he was on leave, but a family story has it that when I began to speak, and he had taken his last one or two weeks' leave off the Eastern front, I said nothing but "der 'dat soll gehn!" - and that "'dat" certainly was not a kid's version of "daddy" but of "Soldat" (soldier). I had not accepted the man in uniform as a family member and wanted him to leave. It was only at the end of his life and the birth of my first daughter (early in 1968, the second was born in the autumn of 1989), that I found this story no longer funny and had acquired enough empathy to feel its bitterness for him.

On the occasion of their tenth wedding anniversary, he had addressed a long love letter in his beautifully styled handwriting to "Dear Peter," including an extended piece about how he had educated her to become a real women and mother, and how proud he was of her, and was signed "Heil Hitler, Dein Bö." When he had returned to the front for the last time, his final joke had been: "Frisier Dich mal!" (Dress up your hair, now and then!) Within a year, however, there were no more personal news from the Eastern front, and my mother produced a whole series of charcoal drawings, showing nothing but a morass with trunks and stumps of dying trees. He was missing. It was only one or two years after the war that she got the news that he was alive, and had been taken prisoner by the Rer. Army. In all, he was put into forced labour camps in Ukraine for more than seven years, partly in mines, later again as medical orderly assisting the camp's female physician, a Jew, of whom he later spoke with the greatest respect.

When he had gone to war, he had ordered my mother not to continue the atelier, but she had nourished us all through the war and post-war by keeping up, and establishing new, client relationships, under the worst of conditions. She carried on to produce her seemingly naïve kitsch that appealed to Allied officers as much as it had done before to German ones, me sitting usually beside her desk playing with my favourite dwarfs and enjoying the virtual harmony as if it were real.

When big bombers approached cities even in southern Germany, she had taken us kids (and her maid), left everything behind in the big apartment and atelier in Stuttgart (of which I know a bit from scarce photographs but almost nothing from my own memory), and sought shelter with her mother and sister, living together in a three-bedroom-apartment in a small town near the Black 
Forest. There, my aunt, the Catholic Fräulein doctor (from my early teens my favourite relative, introducing me to literature and to Catholic cloisters and even taking me along when she first travelled to England and France in the '50s), taught at school. She was the only non-party member on the staff, volunteering instead with the Red Cross, and became headmistress upon the arrival of the French troops, for both of these reasons and because of her fluent French. Mother and kids, owning almost nothing, slept in one room for five years, where my mother also worked at first (the maid having been accommodated in the neighbourhood). Otherwise the old building was big, housing a mysterious cloth warehouse operated, among their many cats, by three elderly spinsters who had inherited this strange business from their father long ago and had left everything as it was. But for my brother and me and a big tomcat, that could frighten me to death hopping suddenly down the staircase like a tiger from nowhere, males simply were absent from this world of my childhood, crammed and odd, as it must have felt to most others.

But for me it was heaven. This was especially so since my grandmother, always in black since her husband had died twenty-five years before, and a small, slender and still energetic figure then approaching eighty, known for her strictness, reigned unchallenged over everything includ-

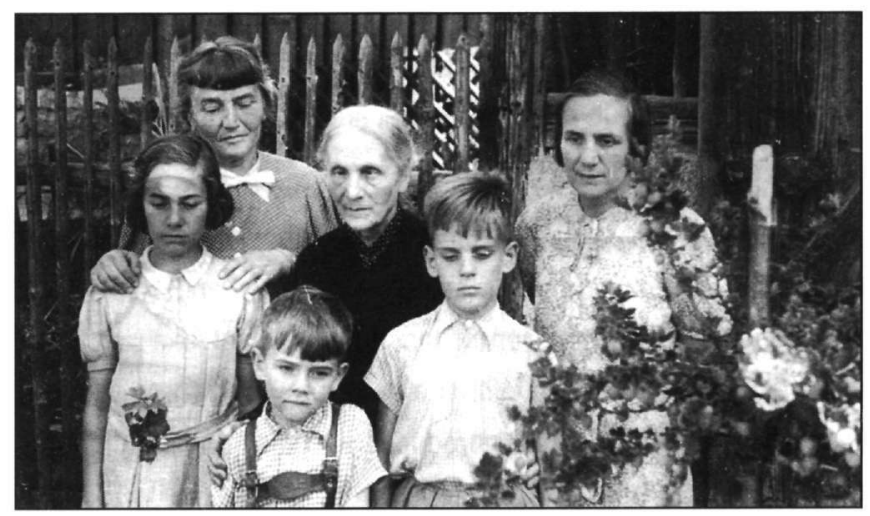

My maternal nest, celebrating in a sad mood probably the confirmation of my sister in 1948: her beloved father was not among the then returning POWs from Russia, and my aunt and grandma were on the verge of moving to a different town. ing her daughters. But she had selected me, the latecomer, to soften in old age and spoil me completely, even admitting me to sod around in the kitchen during her cooking when the place had always been strictly off-limits for anybody else. Everybody respected her authority, not least because she was the only one interested in politics (uncompromising against the Nazis, of course), was well informed and very witty indeed. I guess it was from this gentle, caring and courageous little commander that authority became largely something female for me. To be respected it should live up to such standards and, preferably, it should come together with a special liking for me.

\section{Passing References to Early Escapes}

From the maternal nest I would switch now to stories from elementary school, which I joined in the autumn of 1945 as the youngest among eighty-six kids in the classroom, with a teacher in her early twenties and with maybe a few weeks of training. Re-education came with no textbooks (or later history books without wars), but did involve the reintroduction of the cane by helpless teachers. When more male educators came back from war or de-Nazification, there was a 
growing refinement and hardening of punishment rituals, which frightened and fascinated me, though (or because) I hardly got a stroke. I would tell stories such as one about the Hoover pupils' food, sent in from America to help the younger generation through the hungry years, which the less hungry kids from the surrounding farms poured into the village stream till it was white with milky noodle soup. Or about sports training in military formation commanded by a returned sergeant, with me, pampered and weak as I was, becoming in my teens the worst sport not only of my class, but of my whole school. (In later days I could persuade a nicer teacher in sports to become my advisor on the pupils' paper and let me out of the torture of gym hours and do my editing instead.)

I had only a few friends during the years of elementary school, and they were boys from female families also. With my sister and brother I was close enough in terms of space, but not close enough in terms of age. Outside the house they were in a different bracket and off with the bigger boys, my sister being good at football for instance, and my brother rather early becoming good at girls and playing the hero in all sorts of rebel-ish provocations outdoors or at school. When they returned, occasionally even danger was in the air, because they resented the privileges of the pampered nestling, of course, one day even pushing me, still quite small, into a tiny duck-house together with a dozen or so of these hysterically agitated apocalyptic beasts, just to prove, successfully, what a crying coward and dirty tattletale slept in this quiet sweetheart. I would describe me as a loner and a retarded dreamer, not easily mixing with the country kids around, who regarded urban academics as intruders anyhow and me as spoilt and arrogant. And certainly I would not omit the story of the day when the major part of my class had decided that I merited a good hiding and a whole crowd chased me from the school to our place, me feeling completely innocent of course, and terrified to the bone. I ran for my life, reached home and broke down, and the Doctor diagnosed hidden pneumonia six days gone. This had been the day of the crisis. When I got through, heavens! And how I enjoyed the multiple mothering around in my female retreat during the weeks of my recovery! I could go on telling more such tales about my early education, but maybe this would - with a little help from the interviewer, I lost my track be a good opportunity to find my way back to the return of my father.

\section{The Return of the Warrior}

Three years before, my grandmother and aunt had moved to a nearby town where my aunt no longer had to head the school, but became a more comfortable deputy of a much bigger one (she had no sense for representation; she cared, but tried to evade the exertion of authority). So we could spread out in the apartment. My mother got a room of her own as studio, and I the privilege to be with her after school when she was working and be a first spectator of her results. When my father came back in the early ' 50 s, pictures show a man with eyes staring and little flesh on his bones, aged by much more than a decade. He had retired into himself but was susceptible to sudden outbursts. He recovered only slowly to become a rather successful loser, or broken winner. 
When he had recovered somewhat, a second desk was moved into the studio and I had to quit. My mother allowed him to take charge of the atelier again, within limits, and with the second "economic miracle" under way, it began to flourish again, especially when we moved back to Stuttgart. By connecting his former friends in industry, now completely apolitical business relationships of course, he could give the atelier a big push. My parents were then working in a similar division of labour as before, but not under his name alone. She was behind their more and more modernist designs and less secluded from clients. The main limit, however, was that she carved out the weekends for her painting, step by step working her way back to her abstract origins in the '20s, from the late '50s onwards experimenting with all sorts of mixed techniques. During such weekends, quite often she showed me her results and increasingly debated them with me rather than with my father who fully relied on her in the atelier but remained taciturn about her painting. At the time I did not really understand what her crab's walk was about, or why she mentioned at that time so often her former Jewish friend. Rather, I greatly admired her rapid advance into modernism (in my teens becoming a Bauhaus-fan myself) and felt privileged in watching the development of a great artist. I suggested names for her paintings, because she staged me as her counsel and as a specialist of language, reading every line that I wrote. I cherished her art, which was never exhibited within the lifetime of my father, and thereafter only once.

He hated these weekends and tried to restrain them by suggesting a ride in his cabriolet, recuperated from the woods where his friends during wartime had buried it under a big pile of wood. The car was restored after a rusty decade with the help of a luckier and earlier returned friend from the Soviet camps, who had established a small body shop. Both the car and the ride were attractive family projects and on most weekends, a compromise had to be reached. Otherwise, there was a lot of silence between father and sons and I cannot remember any really open and patient exchange till it was too late (and I had to turn to other witnesses). He could not really transmit his experiences to an audience that knew the end and moral of the story beforehand from school and media, namely that Nazism was criminal and the war insane and lost. But he hardly could talk about anything else, as soon as any comrade from wartime or imprisonment appeared on the scene. I do not even know what my father voted for. The only thing he subscribed to was Readers' Digest, maybe his version of self-re-education. So, somebody else had to do the talking. The advent of television made it possible, and it became a closely observed family ritual in the evening.

The relationships with us kids were differentiated from the start. Only my sister, who had been my father's charming darling in pre-war days, could establish a sort of a warm relationship, despite his decree that she was only allowed to enter the academy of arts after completion of a one year professional housewife training. (In contrast to him, a fine cook, my mother was hardly able to prepare a meal.) Later on she stepped into his tracks and continued the atelier. My brother, however, was in full-fledged puberty when this broken authority came back and wanted to educate his first-born son, whom he knew from before and once even called his "favourite 
son," in the ways of decent masculinity and disciplined responsibility. He got completely carried away. Their clash escalated soon to a catastrophe for them, and years of mediating, first by my mother and, after she was exhausted, by me, were a complete failure in the long run. With me it was different, because at first I simply didn't know what a father was for, regarding the interference of the intruder largely with astonishment and disgust. Frightened by his outbursts and his authoritarian claims rather than respecting his authority I tried to evade clashes and retired into myself even more. Most importantly however, I was protected by my mother, who not only did a lot of day-to-day inter-mediating, but must have set clear limits with regard to the littlest, the admirer and counsel of her art, especially when things with my brother had gone from bad to worse. Under this hidden shelter my encounter with male authority suggested that it was an illegitimate claim, to begin with, arbitrary and unreasonable; in the end, weak or something like a risky force of nature to be evaded rather than confronted, and after all, unlike my grandmother's, it seemed not to come together with a special liking for me.

Then I thought we had almost nothing in common (it took me decades to see, and even longer to accept, our similarities). He was still an impressive sportsman and hated it when I closed myself away reading. Later he was interested neither in my writing nor in my pupils' politics and publishing; and when I finally started in theology, he did not comment but must have felt that I had gone completely nuts. The only thing that really seemed to impress him was that I earned two thirds of my costs as a student myself, neither out of need nor because he would have asked me to, but for independence. To recall all these feelings of the time of my youth is, however, in retrospect very unjust and ungrateful. He made me feel bitter in detail, but how were his feelings? Did he ever interfere with me in matters that mattered? Even when I failed school in my belated puberty, he did not crash down on me or take me out of school, as he had done on the same occasion with my brother some years before, with dreadful results. He made some nasty and well deserved comments but even tolerated that I used the repeating year to start a pupils'

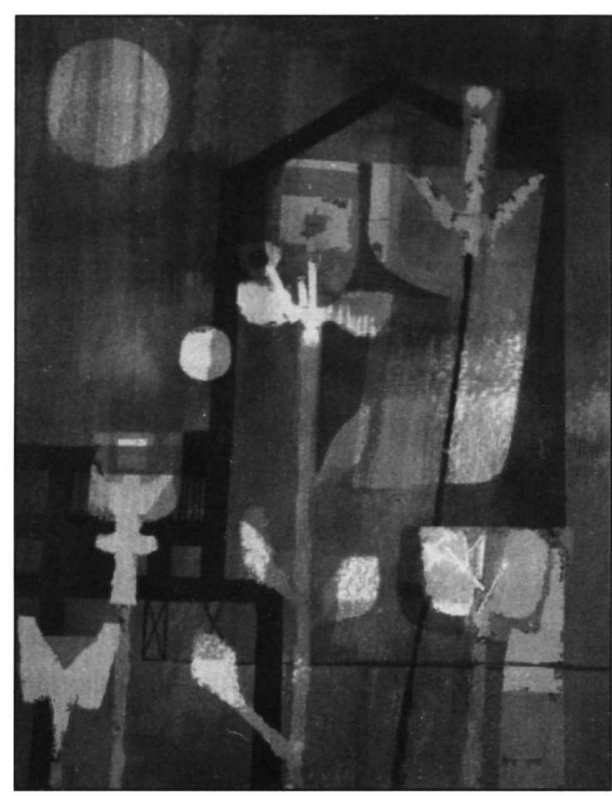

Amo: das Gewächshaus (Gouache, 1958). Handwritten on the back: "Für Lutz - mit großer Freude - zur Erlangung einer gewissen Reife. April 1960" (For Lutz - with great pleasure - for reaching a certain maturity). journal, thereby finally finding my way to the outside world and speeding up in various respects. When at the end of school I finally won the school-prize, and my mother had dedicated a painting to me for reaching "a certain maturity" - a greenhouse blown up by the growth of its flowers - my father spent a week with me at the seaside, the only trip just the two of us ever made 
Living Memory and Historical Practice: A Personal Tale

together. It was a very fine trip in every respect, including the comforts of his big car, and we got along with each other well enough and finally he volunteered to pay for my driver's licence. I had the feeling however, that he wanted to speak, but neither of us found a beginning.

\section{3 Images and Contexts}

Our interviewer seems to be a very patient guy, but now he sees his chance to get his foot in the door of this longish version of an Oedipus complex, and says: Sad enough. But tell me one thing: Do you really want me to believe that you have no wartime recollections whatsoever? None at all, besides that you liked your grandma? I mean, you were beyond the age of five when the Allies were coming. The interviewee strikes back and quotes a French proverb: happy people have no memory. But the interviewer doesn't give up: I am sure there must be at least some images or scenes. The interviewee doesn't want to be regarded as abnormal and says: Well, there may be three or four (in actual fact, three of them had always been present in his repertoire) and let me start with liberation day, and I hope I can work my way backwards.

\section{Liberation Day}

Certainly, I will always remember the day when the French forces took our town. There was no shooting, and all German males had fled. The French turned out to be rather dark people from southern Morocco and staged a highly romantic feast of victory in front of our place, slaughtering and roasting some sheep, after one of them had requisitioned the longest knife from grandma's kitchen, later bringing it back to the old lady in his mouth, carrying in his hands a whole plate of sweets for the fair-headed kids. Since my aunt wore her uniform as a nurse of the Red Cross and spoke French, the women's house stayed off-limits. But the best for me was still to come. The troops thought that a German counter-attack was due from the other side of the valley (which never came). They positioned their tanks, moving them backwards near our house, crushing almost every one of the stone plates surrounding the building, which the spinsterowners from below had defended against my wooden scooter (which didn't work elsewhere because there was no smooth pavement in the vicinity), because it might have harmed the stone. The sound, when the tanks crunched this rather longish line of plates, was a hymn of victory for me, even though my scooter now had fewer opportunities to work somewhere in this unpaved neighbourhood. (The interviewer cannot but comment: Obviously you could also hate female authorities when they were not instrumental for your privileges.)

\section{Under the Pear Tree}

It was a few weeks earlier that the first air-attack had hit our small town. I had seen a group of men in strangely striped clothes being led to and from a former salt mine in town (to be transformed into a subterranean ammunitions factory, as I later learned). And, of course, there were foreign workers in town, who strangely enough didn't hide in the shelters (they were not allowed) when the bombing siren sent us others to the cellar. This time I had seen one of them hiding 
under the pear tree in the spinsters' garden in front of the house. There was a big noise, originating from a small low-flying aircraft, and when we returned from our shelter, all houses around were in fairly good shape but for a few broken windows. But the garden was a complete mess and where the pear tree had been, and the foreign worker, there simply was an enormous hole in the earth. I have only a glimpse of that sight in my mind, because we kids were quickly turned into the house and the shutters to the garden were closed.

\section{Magic in the Kitchen and Other Envelopes of Loss}

The third picture I can recover from my memory has to be placed in time a year earlier. It is bound to be associated with great emotions, otherwise it would not be available amid the many other wartime/childhood images lost. Probably because there had been a bombing warning for the Southwest in the broadcasting, all of us were sitting round the kitchen table late at night, but no local alarm came. The window of the kitchen was facing north, Stuttgart being fifty miles away, and the night-sky was simply red and grey. Not only I, but nobody had ever seen such a spectacle and we were all very quiet. Suddenly grandma broke into the silence: "This time it's ours." What I do remember is just the image of the red sky, framed by the kitchen window, the emotional strain in the room, and grandma's laconic message. It became also an icon within family legend, because during the next days it turned out that she had been right. The big apartment of my parents, where my mother was born, had gone with everything, including all of their work, good and bad.

In the nestling's memory, however, the icon is focused on the unusual then and there in the kitchen, the frightening miracle and the magic authority, and is not associated with the feeling of loss that must have been the basic emotion of the others around. So the significance of the event comes from legend, where a deeply emotional trauma quite often is wrapped in a cool account of a dramatic event, survival, garnished with frivolous detail, even when the event as such was encountered at a safe distance. So family legend has woven the magic icon

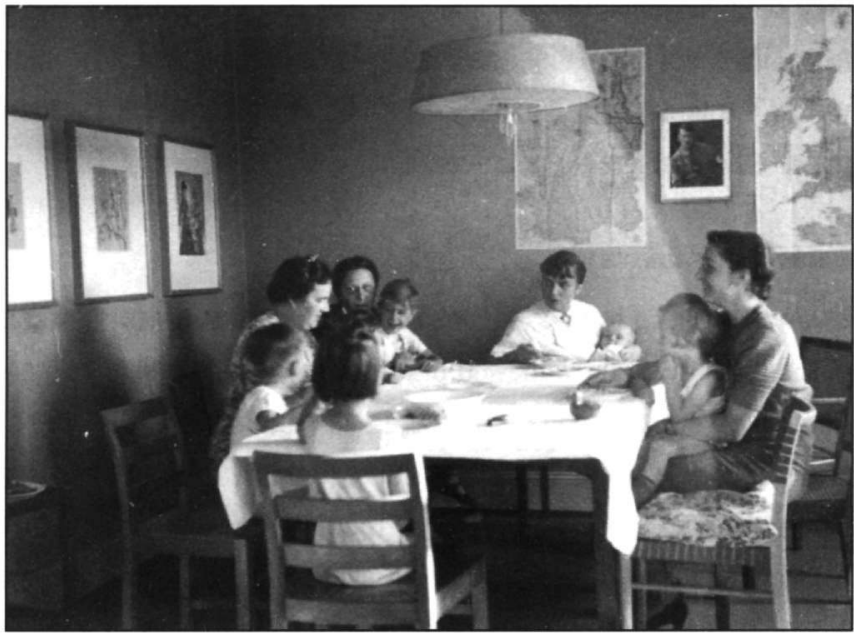

Beyond recollection a document from the family archives: in the Stuttgart apartment in 1940 my mother (facing the camera and holding the nestling in her arm) together with my father's sister and his brothers' wives and all the kids. Note the two maps on the wall, where the womenfolk on the home front followed the moves of their husbands in Eastern and Western Europe, amidst - above my head - the framed picture of the Führer. 
Living Memory and Historical Practice: A Personal Tale

and the feeling of loss together with the following story: The news was brought by a surviving neighbour and was quite closely modelled on the messengers to Job, with a bit of slapstick. She had started late after the bombing alarm and, running down, had overthrown a flowerpot. As a good housewife she went back to the kitchen to clean the water from the sideboard, and then continued to run down. Because there was a terrible noise, she was lucky not to head for the cellar but for the street, because when she was hardly out, the whole apartment block behind her came down, hit by high-explosion bombs, together with various other houses in the street. And since the neighbourhood was uphill, she was not caught by the onset of the firestorm that in this night wiped out much of the inner city. She said, it would not pay to go back and have a look: only rubble.

\section{4 The Challenge of the Unintegrated}

Probably then an impulse from the interviewer would be needed, like: When all was gone, what were you left with as toys? Do you remember a favourite object in the secluded world of your wartime childhood? The interviewee could immediately point to the completely worn out teddy called Wönne (alluding to bliss) that accompanied him well into puberty, but even more than the tiny plaster dwarfs peopling the world of his fantasy and play, Wönne had then been a companion rather than an object. Hesitatingly, however, I could - as sort of an unintegrated postscript offer a fourth icon, that only recently has been revived from sunken layers of my memory. The interviewer would have to suck it with his curious eyes from his interviewee's lips, so that he could follow his associations and surmount his hesitation, because this object clearly had not only been absent from his interpretation of his childhood, but is difficult to integrate into his narrative, if not altogether challenging to its construction. The interviewee is flattered by the interviewer's interest and hopefully falls into his trap. Since German madeleines sometimes taste rather bitter and are all but redeeming.

\section{Eastern Railway}

Two years ago, I toured Eastern Europe as a government advisor, in search of both the number of people concerned with, and practical ways to transmit, compensation for Nazi forced labour. Being in Belarus I knew of course as an historian that the ghetto of Minsk had been one of the worst Eastern centres of the Holocaust (but it was different to stand on the small memorial site, where it once had been), and that more generally the German war of annihilation against the Slavonic population as well in Belorussia had caused the most dramatic drop in population anywhere in Europe. By the end of the war, the capital city of Minsk had almost perished and other major places like Mogiljow had also been affected in the most horrible ways. In the evening the president of the Jewish community in Belarus took me out for dinner and brought an old lady along who had survived as the only one from a large Jewish family. Being driven to the ghetto at the age of sixteen, she had managed to escape and change her identity and was sent as a Slavonic girl to the Reich, to work in industry and agriculture. I was the first German she ever met 
since liberation (meaning for her also repression from Soviet authorities since the war), and she talked about harsh treatment in mills and miserable conditions in camps, of which she could remember neither names nor localities, but also of humane behaviour and enough to eat on a farm in northeastern Germany. Among all her tears and transferences she insisted again and again that this farmer had looked exactly like me. When I asked her where she had come from, her answer sounded like "Mahiljów," but she helped me, "Germans pronounced it Mógilew."

In the night I could not sleep for many reasons, one of them being that an image had come up from early childhood: one of my favourites among the few toys we then had. It was a big wooden locomotive, produced by Russian handicraft. I do not remember how it arrived and whether it belonged to me or to my brother, or to both of us. Had my father sent it from the Eastern front or had he brought it with him as a gift on that last visit, when I wanted the soldier to leave? Anyhow, he had left an object of desire with me that now, in my sleepless night at Minsk, seemed to send out all sorts of questions as to its implied significances and intriguing relationships. On another layer it seemed to imply desires between father and sons that my conscience had denied deciphering. I only knew that I had cherished it. And it was intriguing to see a favourite object within that feminine idyll of my secluded wartime childhood symbolising power and advance and relate it to one of the worst places of German rule in Russia, where my father had been stationed. He had painted the wooden locomotive in gay colours and on top, as sign of origin or destination, there was printed not in Cyrillic, but in German black capital letters MOGILEW. Favourite and cheerful as this special toy was, this object of desire had not been left behind at Stuttgart, but was one of the few to be rescued into my female nest near the Black Forest. Since everybody around called it the "Mogilew-lokomotive," this must have been among the first words I could read, or at least connect signifiers to sound. It took me long to connect them to significance, and I am still only approaching its reading.

As many an interviewee, feeling somewhat exhausted and riddled by the process of recollection, seducing him far beyond what he wanted to say, I probably would now ask my interviewer: Can we leave it at that, for this time? Obviously the interviewer now would like to go on and on, searching the associative track of dynamic objects into the interviewee's mind. (He already had alluded to a scooter and a curious cabriolet of his father's, and on the desk of the old history professor stood surprisingly enough a model car, a black wartime Citroën $11 \mathrm{CV}$, just for starters.) Or should he put another question, opening up the world of his puberty and beyond, that the interviewee had already alluded to as a very different and more dynamic one, and thereby intruding into new departments within his memory and self-understanding? But since it is a basic rule of any semi-public interview, that such a demand of a riddled interviewee for a pause must be respected, let's leave it at that, for this time. 


\section{Appendix: Bibliography}

\section{Books in German:}

- Angepaßter Faschismus. Politische Praxis der NPD. Frankfurt am Main: S. Fischer, 1969, 288 S.

- Entnazifizierung in Bayern. Säuberung und Rehabilitierung unter amerikanischer Besatzung. Frankfurt am Main: S. Fischer, 1972, 710 S.; 2. Auflage unter dem Titel Die Mitläuferfabrik. Berlin/Bonn: Dietz, 1982, $717 \mathrm{~S}$.

- (Hg.) Walter L. Dorn - Inspektionsreisen in der US-Zone. Stuttgart: Deutsche Verlags-Anstalt, 1973, 178 S.

- (Mit-Hg. mit Peter Brandt und Ulrich Borsdorf) Arbeiterinitiative 1945. Antifaschistische Ausschüsse und Reorganisation der Arbeiterbewegung in Deutschland. Wuppertal: Hammer, 1976, 782 S.

- (Mit-Hg. mit Ulrich Borsdorf) Zwischen Befreiung und Besatzung. Analysen des US-Geheimdienstes über Positionen und Strukturen deutscher Politik 1945. Wuppertal: Hammer, 1977, 351 S.; 2. Auflage Weinheim: Beltz Athenäum, 1995.

- Umständliche Erläuterung der seelischen Störung eines Communalbaumeisters in Preußens größtem Industriedorf oder Die Unfähigkeit zur Stadtentwicklung. Mit grafischen Anmerkungen von Hermann Sturm. Frankfurt am Main: Syndikat, 1979, $110 \mathrm{~S}$.

- (Hg.) Wohnen im Wandel. Beiträge zur Geschichte des Alltags in der bürgerlichen Gesellschaft. Wuppertal: Hammer, 1979, 432 S.

- (Hg. unter Mitarbeit von Werner Trapp) Lebenserfahrung und kollektives Gedächtnis. Die Praxis der "Oral History." Frankfurt am Main: Syndikat, 1980, 375 S.; als Taschenbuch mit neuem Vorwort Frankfurt am Main: Suhrkamp, 1985, $510 \mathrm{~S}$.

- (Hg.) Lebensgeschichte und Sozialkultur im Ruhrgebiet 1930-1960. 3 Bde.: Bd. 1 "Die Jahre weiß man nicht, wo man die heute hinsetzen soll." Faschismuserfahrungen im Ruhrgebiet. (2. Auflage 1985), 327 S.; Bd. 2 "Hinterher merkt man, daß es richtig war, daß es schiefgegangen ist." Nachkriegserfahrungen im Ruhrgebiet. 360 S.; Bd. 3 (Mit-Hg. Alexander von Plato) "Wir kriegen jetzt andere Zeiten." Auf der Suche nach der Erfahrung des Volkes in nachfaschistischen Ländern. 468 S. Berlin/Bonn: Dietz, 198385 (Neuausgabe 1985).

- (Mit-Hg. mit Ulrich Borsdorf, Bodo Hombach und Tilman Fichter) "Die Menschen machen ihre Geschichte nicht aus freien Stücken, aber sie machen sie selbst." Einladung zu einer Geschichte des Volkes in NRW. Berlin/Bonn: Dietz, 1984, 267 S.; 2. Auflage 1985.

- (Mit-Hg. mit Othmar Nikola Haberl) Marshallplan und Europäische Linke. Frankfurt am Main: Europäische Verlagsanstalt, 1986, $659 \mathrm{~S}$.

- (mit Dorothee Wierling) Geschichte in der Bundesrepublik Deutschland. Ein Studienführer. Bonn: DAAD, 1986.

- Posthistoire. Ist die Geschichte zu Ende? Unter Mitarbeit von Dirk van Laak. Reinbek: Rowohlt, 1989, $190 \mathrm{~S}$.

- (Koautor) Bürgerliche Gesellschaft in Deutschland. Historische Einblicke, Fragen, Perspektiven. Frankfurt am Main: Fischer, 1990, $718 \mathrm{~S}$.

- (Mit-Hg. mit Bernd Weisbrod) Hans Mommsen. Der Nationalsozialismus und die deutsche Gesellschaft. Ausgewählte Aufsätze. Reinbek: Rowohlt, 1991, 448 S.

- (mit Alexander von Plato und Dorothee Wierling) Die volkseigene Erfahrung. Eine Archäologie des Lebens in der Industrieprovinz der DDR. 30 biografische Eröffnungen. Berlin: Rowohlt Berlin, 1991, $650 \mathrm{~S}$.

- (Hg.) Wissenschaftszentrum Nordrhein-Westfalen - Kulturwissenschaftliches Institut. Das Gründungsjahr. Bericht. Essen 1991 (Red. Norbert Jegelka); dass. Bericht 1991, Essen 1992 (Red. Norbert Jegelka).

- (Hg.) Der "gesäuberte" Antifaschismus. Die SED und die roten Kapos von Buchenwald. Unter Mitarbeit von 
Harry Stein und Leonie Wannenmacher eingeleitet und kommentiert von Karin Hartewig und Lutz Niethammer. Berlin: Akademie, 1994, 566 S.

- (Mit-Hg. mit Christian Jansen und Bernd Weisbrod) Von der Aufgabe der Freiheit. Politische Verantwortung und bürgerliche Gesellschaft im 19. und 20. Jahrhundert. Festschrift Hans Mommsen. Berlin: Akademie, 1995, $758 \mathrm{~S}$.

- (Mit-Hg. mit Sergej Mironenko, Alexander von Plato u.a.) Sowjetische Sonderlager in der SBZ, 2 Bde.: Bd. 1 Studien und Berichte. Hg. v. Alexander von Plato. 595 S.; Bd. 2 Dokumente zur Lagerpolitik. Bearbeitet von Ralf Possekel. 424 S. Berlin: Akademie, 1998.

- Deutschland danach. Postfaschistische Gesellschaft und nationales Gedächtnis. Hg. von Ulrich Herbert und Dirk van Laak in Zusammenarbeit mit Ulrich Borsdorf, Franz-Josef Brüggemeier, Alexander von Plato, Dorothee Wierling und Michael Zimmermann. Bonn: Dietz, 1999, 623 S.

- Kollektive Identität. Heimliche Quellen einer unheimlichen Konjunktur. Unter Mitarb. von Axel Doßmann. Reinbek: Rowohlt, 2000, 680 S.

\section{Texts in English}

- "Anti-Fascism in Post-War Germany," in Raphael Samuel (ed.), People's History and Socialist Theory. London: Routledge, 1981, pp. 211-4.

- "Some Elements of the Housing Reform Debate in 19th C. Europe: or, On the Making of a New Paradigm of Social Control," in Bruce M. Stave (ed.), Modern Industrial Cities. History, Policy and Survival. Beverly Hills/London: Sage, 1981, pp. 129-64.

- "Oral History as a Channel of Communication between Workers and Historians," in Paul Thompson with Natasha Burchardt (eds.), Our Common History. The Transformation of Europe. London: Pluto Press, 1982, pp. 23-37.

- (with Franz Brüggemeier) "Lodgers, Schnapps-Casinos and Working-Class Colonies in a Heavy-Industrial Region," in George Iggers (ed.), The Social History of Politics. Critical Perspectives in West German Historical Writing Since 1945. Leamington Spa: Berg, 1985, pp. 217-58.

- "Reconstruction and Disintegration. The German Labor Movement between War and Cold War," Radical History Review, 37 (1987), pp. 7-25.

- "Afterthoughts on Posthistoire," History and Memory, 1 (1989), pp. 27-53.

- "Where Were You on 17 June? A Niche in Memory," in Luisa Passerini (ed.), Memory and Totalitarianism. International Yearbook for Oral History and Life Stories. Vol. 1. Oxford: Oxford University Press, 1992, pp. 45-69.

- Posthistoire. Has History Come to an End? London/New York: Verso, 1992. 3rd edition 1994 [in German 1989].

- "The Structuring and Restructuring of the German Working Classes after 1945 and after 1990," The Oral History Review 21 (1993), pp. 9-18.

- "Zeroing in on Change. In Search of Popular Experience in the Industrial Province in the German Democratic Republic," in Alf Lüdtke (ed.), The History of Everyday Life. Reconstructing Historical Experiences and Ways of Life. Princeton: Princeton University Press, 1995, pp. 252-311 [in German 1988].

- "The German Sonderweg After Unification" in Reinhard Alter and Peter Monteath (eds.), Rewriting the German Past. History and Identity in the New Germany. Atlantic Highlands, NJ: Humanities Press 1997, pp. 129-51 [in German 1991.]

- "Maurice Halbwachs. Memory and the Feeling of Identity," in Bo Stråth (ed.), Myth and Memory in the Construction of Community. Historical Patterns in Europe and Beyond. Bruxelles: Peter Lang, 2000, pp. 75-94 
- "A European Identity?" in Bo Stråth (ed.), Europe and the Other and Europe as the Other. Bruxelles: Peter Lang, 2000, pp. 87-112.

- "'Normalization' in the West. Traces of Memory Leading Back into the 1950s," in Hanna Schissler (ed.), The Miracle Years. A Cultural History of West Germany, 1949-1968. Princeton, NY: Princeton University Press, 2001, pp. 237-65 [in German 1987]. 